\title{
Umur Bey Taş Vakfiyesi: \\ Esin ve İçerik Üzerine Bir Değerlendirme
}

Mustafa Çă̆han Keskin*

Waqf Inscription of Umur Beg: A Study on Inspiration and Context

Abstract - The waqf inscription located at the mosque that was built by Umur Bey, is one of the earliest serious attempts in Ottoman cultural world, representing daily Turkish spoken by common people have been transferred from paper to public space. Umur Bey was influenced and inspired by the commisioner of the Turkish waqf inscription in Kütahya, Germiyanoğlu II. Yakup, an intellectual member of governor elite, whom he knew for several years. Umur Bey's preference of Turkish language, whom was a part of the Turkish elite that lost its prestige among Ottoman bureaucracy, does not only show the significance he gives to his mother tongue but also points out the fact that he was worried that the majority of the public was unable to understand Arabic and that the text could be easily understood. Announcement of the waqfiya [the deed of the endowment] in the public space, coincides with the land reform of Sultan Mehmed II, anticipating nationalization of the landed properties, that are foundations' main sources of income. This gives an impression that Umur Bey gives a reaction to this land reform, by proclaiming his devoted territory.

Keywords: Ottoman Architecture, Ottoman Inscriptions, Waqfs, Umur Bey, Bursa.

Osmanlı mimari pratiğinde, yapı hakkında bilgi veren yazıt genellikle temelde yapının işlevi, banisi ve inşa tarihini bildiren inşa kitabeleridir. Yapının işleyişini detaylı şekilde açıklayan vakfiyeler ise çoğunlukla taşınabilir belge niteliğinde olup, vakfiyenin yapı üzerinde bir yazıt ile temsil edilmesi yaygın bir uygulama değildir. ${ }^{1}$ On beşinci yüzyıl Osmanlı ortamının tanınmış figürlerinden

* Kadir Has Üniversitesi.

1 Gönül Cantay, “Türklerde Vakıf ve Taş Vakfiyeler”, Vakıf Kültür Varlığının Korunması, Yaşatılması ve Bu Amaçla Malî Kaynak Sağlanması Semineri Bildiriler (Ankara: Vakıflar Genel Müdürlüğ̈̈ Yayınları, 1994), s. 147-162. 
Umur Bey'in Bursa'da inşa ettirdiği caminin kuzey duvarında yer alan taş vakfiyesi Osmanlı mimarlığında bu uygulamanın sınırlı sayıdaki örneklerinden biridir. Daha önce çeşitli araştırmacıların dikkatini çekmiş olan vakfiye metni, özellikle transkripsiyon ve vakfın işleyişine ilişkin içeriği üzerine odaklanan farklı çalışmalarla yayınlanmıştır. ${ }^{2}$ Umur Bey'in Arapça vakfiye metnini gündelik-sade bir Türkçe’ye tercüme ettirerek bir yazıtla ilan etmesinin arkasındaki esin kaynağı, etken ve motivasyonlar üzerinde durulmamıştır. Bu araştırma, vakfiye düzenlemesini, Umur Bey'e örnek olan, ona esin ve cesaret veren benzer uygulamalar ile birlikte tartışan; vakfiye metninin bu şekilde topluma ilan edilmesindeki olası motivasyonlara ilişkin yeni bir yaklaşım ortaya koymayı amaçlayan bir değerlendirme denemesidir.

Umur Bey’in nerede ve ne zaman doğduğu bilinmemektedir. Babası Yıldırım Bayezid'in vezirlerinden Kara Timurtaş Paşa'dır. ${ }^{3}$ Siyasi kariyerine ilişkin ilk kayıt, 793/1391 yılındaki İstanbul kuşatmasına katıldığı yönündedir. ${ }^{4}$ 805/1402 yılında Ankara Savaşı'nda babası ile birlikte Timur'a esir düşmüştür. ${ }^{5}$ Esaretini takip eden dönemde Rumeli'de Musa Çelebi'nin yanında yer aldığı anlaşılmaktadır. ${ }^{6}$ Çelebi Sultan Mehmed'in kardeşi Musa Çelebi'yi bertaraf etmesinin ardından onun

2 Abdülhamit Tüfekçioğlu, Erken Dönem Osmanlı Mimarisinde Yazı (Ankara: Kültür Bakanlığı Yayınları, 2001), s. 315-316. Okuma farklılıkları için: Ekrem Hakkı Ayverdi, Osmanlı Mimârîsinde Çelebi ve II. Sultan Murad Devri 806-855 (1403-1451) (İstanbul: İstanbul Fetih Cemiyeti, 1989b), s. 339-340; Kâmil Kepecioğlu, Bursa Kütü̆ğ̈, IV, haz. Hüseyin Algül, Osman Çetin, Mefail Hızlı, Mustafa Kara M. Asım Yediyıldız (Bursa: Bursa Büyükşehir Belediyesi, 2009), s. 196-197; Ahmed Tevhid (Ulusoy), "Bursa'da Umur Bey Cami Kitabesi”, Tarih-i Osmanî Encümeni Mecmuası, 14 (İstanbul 1328), s. 865-872; Kâzım Baykal, Bursa ve Anttları (Bursa: Hakimiyet Tesisleri, 1993), s. 199-201; Muallim Cevdet, "Bursa'da Gazi Umur Bey Camii Kitâbesi ve Bir Kaç Mühim Kitap”, Türk Tarih Arkeoloji ve Etnoğrafya Dergisi, II (Ankara 1934), s. 258-261; Memduh Turgut Koyunluoğlu, İzik ve Bursa Tarihi (Bursa: Bursa Vilayet Matbaası, 1935), s. 178-180; Halim Baki Kunter, "Kitabelerimiz", Vakıflar Dergisi, II (1942), s. 445-446; Robert Mantran, "Les Inscriptions Turques de Brousse”, Oriens, XII (1959), s. 118-121, Türkiye’de Vakıf Abideler ve Eski Eserler, III (Ankara: Vakıflar Genel Müdürlüğü, 1983), s. 145-147.

3 Feridun Emecen, "Timurtaş Paşa”, TDV İslâm Ansiklopedisi (DİA), XLI (Ankara 2012), s. $185-186$.

4 Aşık Paşazade, Osmanoğullarının Tarihi: Tevârih-i Al-i Osmân, haz. Kemal Yavuz, M. A. Yekta Saraç (İstanbul: Gökkube Yayınları, 2010), s. 339.

5 Kepecioğlu, Bursa Kütüğ̈̈, s. 194.

6 Mehmed Hemdemî Çelebi Solak-Zâde, Solak-Zâde Tarihi, I, haz. Vahid Çabuk (Ankara: Kültür Bakanlığı Yayınları, 1989), s. 166; Hoca Sadeddin Efendi, Tâcü't Tevârih, II, haz. İsmet Parmaksızoğlu (İstanbul: Kültür Bakanlığı Yayınları, 1992), s. 73. 
hizmetine giren Umur Bey, Ankara Savaşı'nı izleyen Fetret Dönemi'nde Bizans tarafından ele geçirilen İstanbul çevresindeki Darıca, Gebze, Pendik ve Kartal çevresinde Osmanlı hakimiyetini sağlamakla görevlendirilmiştir. ${ }^{7}$ Çelebi Sultan Mehmed'in ölümünden sonra, Düzme Mustafa olayındaki yararlılıklarından dolayı II. Murad tarafından Aşııpaşazade’nin tabiriyle “ilçi” sıfatıyla Kütahya’ya gönderilmiştir; "Germiyanoglina ilçiliğe göndürdi kim ol Kara Temürtaş oglı Umur Beg'dür”. ${ }^{8}$ Aşıkpaşazade'nin bahsettiği 'ilçilik' diplomatik bir ziyaretten ziyade, Çelebi Sultan Mehmed döneminden itibaren Osmanlı'nın vasalı konumundaki Germiyanoğlu Beyliği’’nde kalıcı bir temsilciliktir. ${ }^{9}$ Bu görevi ne kadar yürüttüğü bilinmemektedir. ${ }^{10}$ Umur Bey, 834/1432 yılında Timurlu hükümdarı Şahruh'un baskısından kaçarak II. Murad'ın izniyle Tokat'ta kışlayan ancak baharla birlikte çevreyi yağmalamaya girişen Karakoyunlu İskender Mirza’nın bölgeden uzaklaştırılması için Amasya valisi Yörgüç Paşa’nın yardımına giden orduya komuta etmiş ve başarılı olmuştur. ${ }^{11}$ Siyasi kariyeri hakkında başka bir bilgi bulunmayan Umur Bey’i çağdaşı Rum tarihçi Doukas, "yiğgit ve savaşta yenilmez" şeklinde över. ${ }^{12}$

Siyasi kariyerinden ziyade imar faaliyetleri ve Osmanlı kültür-sanat ortamına katkılarıyla tanınan Umur Bey, 859/1454-1455 tarihli vakfiyesine göre, ${ }^{13}$ Biga'da bir cami, ${ }^{14}$ Bergama'da bir medrese, ${ }^{15}$ (Afyon) Karahisar'da bir cami ${ }^{16}$ ve bir medrese, ${ }^{17}$ Bursa'da bir cami ile bunların bakım, onarım ve işleyişi için Bergama'da

7 Hoca Sadeddin Efendi, Tâcǜt Tevârih, s. 108-109.

8 Aşık Paşazade, Osmanoğullarının Tarihi, s. 376.

9 Tim Stanley, “The Books of Umur Bey”, Muqarnas, XXI (2004), s. 323-332.

10 Osmanlı kaynaklarına bakılırsa, Umur Bey bu görevi daha sonra Varna Savaşı'nda şehit olan oğlu Osman Çelebi'ye devretmiştir [Aşık Paşazade, Osmanoğullarının Tarihi, s. 399; Mehmed Neşrî, Neşrî Tarihi, II, haz. Mehmet Altay Köymen (Ankara: Kültür ve Turizm Bakanlığı Yayınları, 1984, s. 105].

11 Hoca Sadeddin Efendi, Tâcüt Tevârih, s. 73; Solak-Zâde, Solak-Zâde Tarihi, s. 222.

12 Mikhaèl Doukas, Tarih: Anadolu ve Rumeli (1326-1462), çev. Bilge Umar (İstanbul: Arkeoloji ve Sanat Yayınları, 2008), s. 149.

13 Umur Bey’in vakfiyesi Vakıflar Genel Müdürlüğü Arşivi’nde bulunmaktadır: VGMA, 591/181-182. Ayrıca bakınız: Bursa Vakfiyeleri, I, haz. Hasan Basri Öcalan, Sezai Sevim, Doğan Yavaş (Bursa: Bursa Büyükşehir Belediyesi Kültür A.Ş., 2013), s. 478-503.

14 Günümüze ulaşamamıştır.

15 Günümüze ulaşamamıştır. Ayverdi, Osmanlı Mimârî̀sinde Çelebi ve II. Sultan Murad Devri, s. 270; Mustafa Bilge, İlk Osmanlı Medreseleri (İstanbul: İstanbul Üniversitesi Edebiyat Fakültesi Yayınları, 1984), s. 166.

16 Günümüze ulaşamamıştır. Ayverdi, Osmanlı Mimârîsinde Çelebi ve II. Sultan Murad Devri, s. $211-213$.

17 Günümüze ulaşamamıştır. Bilge, İlk Osmanlı Medreseleri, s. 161. 
bir hamam, Biga'da bir hamam, Bursa'da bir hamam ${ }^{18}$ ve han, ${ }^{19}$ Karahisar'da bir han ve hamam ${ }^{20}$ inşa ettirmiştir. Ayrıca, Bursa'da bir açık namazgah ${ }^{21}$ ile Edirne'de bir mescid ${ }^{22}$ yaptırmıştır.

Osmanlı tarihinde kişisel kitap koleksiyonuna sahip olan ve kütüphane kuran ilk entelektüellerden biri olan Umur Bey'in 843/1440 tarihli en eski vakıfnamesinde, Bergama’da inşa ettiği medresenin müderris ve öğrencilerinin faydalanması için çeşitli kitaplar vakfettiği görülmektedir. Bursa’da inşa ettirdiği camiye de cemaatin faydalanması için çok sayıda kitap vakfetmiş ve caminin müezzinini bir akçe yevmiye ile kitaplığının sorumlusu (hafız-1 kütüb) tayin etmiştir. Kitaplarına çok fazla önem veren Umur Bey, bunların medrese ve camiden dışarı çıkarılmamasına özen göstermiştir. 853/1449 tarihli başka bir kayıtta, babası Timurtaş Paşa’nın inşa ettirdiği imarete yirmi dördü Türkçe olmak üzere altmış cilt kitap vakfetmiş ve imaret şeyhini kitaplardan sorumlu tutmuştur. 859/1454 tarihli bir diğer vakıfnamesine göre, Bursa’daki camisine cemaatin yararlanması üzere vakfettiği kitap sayısının toplamda üç yüz alıı cilde ulaşmıştır. ${ }^{23}$

18 Kepecioğlu, Bursa Kütüğ̈̈, s. 197; Ayverdi, Osmanlı Mimârîisinde Çelebi ve II. Sultan Murad Devri, s. 345-346.

19 Kepecioğlu, Bursa Kütüğ̈̈, s. 197-198.

20 Günümüze ulaşamamıştır.

21 Kepecioğlu, Bursa Kütü̈̆̈̈, s. 198; Albert Gabriel, Bir Türk Başkenti Bursa, çev. Neslihan Er, Hamit Er, Aykut Kazancıgil (Bursa: Osmangazi Belediyesi Yayınları, 2010), s. 153-154; Ayverdi, Osmanlı Mimârîisinde Çelebi ve II. Sultan Murad Devri, s. 329-330.

22 Günümüze ulaşamamıştır. Umur Bey'in adını taşıyan mahallede bulunan yapı yanındaki türbeye izafen Tirid Baba Camisi olarak da anılmaktaydı [Ahmed Bâdî Efendi, Riyâz-ı Belde-i Edirne: 20. Yüzyıla Kadar Osmanlı Edirne’si, haz. Niyazi Adıgüzel, Raşit Gündoğdu (İstanbul: Trakya Üniversitesi, 2014), s. 139; ayrıca; Ayverdi, Osmanlı Mimârîsinde Çelebi ve II. Sultan Murad Devri, s. 422].

23 Umur Bey’in Kütüphanesi üzerine: İsmail E. Erünsal, Türk Kütüphaneleri Tarihi II: Kuruluştan Tanzimat’a Kadar Osmanlı VakıfKütüphaneleri (Ankara: Atatürk Kültür Merkezi, 1991), s. 9-11; İsmail E. Erünsal, "Umur Bey Kütüphanesi”, TDV İslâm Ansiklopedisi (DİA), XLII (Ankara 2012), s. 159-160. Timurtaş Paşa İmareti’ne vakfedilen kitapların ayrıntılı listesi için; Stanley, "The Books of Umur Bey”, s. 325-326; Murat Yüksel, "Kara Timurtaşoğlu Umur Bey’in Bursa'da Vakfettiği Kitaplar ve Vakıf Kayıtları”, Türk Dünyası Araştırmalar, XXXI (1984), s. 134-147. Umur Bey’in vakfettiği kitaplardan günümüzde Bursa İnebey Kütüphanesi'nde bulunanlar hakkında: Hüseyin Gürsel Bilmiş: "Bursa İnebey Kütüphanesindeki Ortaçağ İslam Ciltterinin (13-14. Yüzyıl) Cilt Sanatı Açısından Değerlendirilmesi” (yüksek lisans tezi), İstanbul: Mimar Sinan Güzel Sanatlar Üniversitesi Sosyal Bilimler Enstitüsü, 2013. Koleksiyon, Kur'an tesfirleri, tarih, edebiyat ve tıp kitapları gibi geniş bir içerik skalasına sahiptir. Bir kısmı günümüze kadar ulaşamamıştır. 
Umur Bey, mezar taşında belirtildiği üzere, Zi'l-kade 865/Ağustos 1461 tarihinde öldügünde, Bursa’da inşa ettirdiği caminin yanında bulunan türbesine defnedilmiştir. ${ }^{24}$ İnşa ettirdiği yapılar arasında en prestijli ve vakfiyesinden anlaşıldığına göre en yüksek vakıf gelirini bağışladığı hayratı olan bu caminin, II. Murad döneminde tamamlandığı anlaşılmaktadır. ${ }^{25}$ Cami, aralarında kemerli bir geçiş açıklığı bulunan kubbeyle örtülü farklı büyüklüklerde iki ayrı kare mekan ile bunların önündeki dört sütunlu kubbeyle örtülü bir revaktan meydana gelmektedir. ${ }^{26}$ Doğu yönündeki, diğerine göre daha küçük olan birim, olasılıkla Umur Bey'in kitaplarının yerleştirildiği bölümdür. Mihrap, batı yönündeki birimde yer almaktadır. Minare, bu birimin kuzey batı yönünde yer almakta ve giriş kapısı son cemaat revağına açılmaktadır (Figür 1).
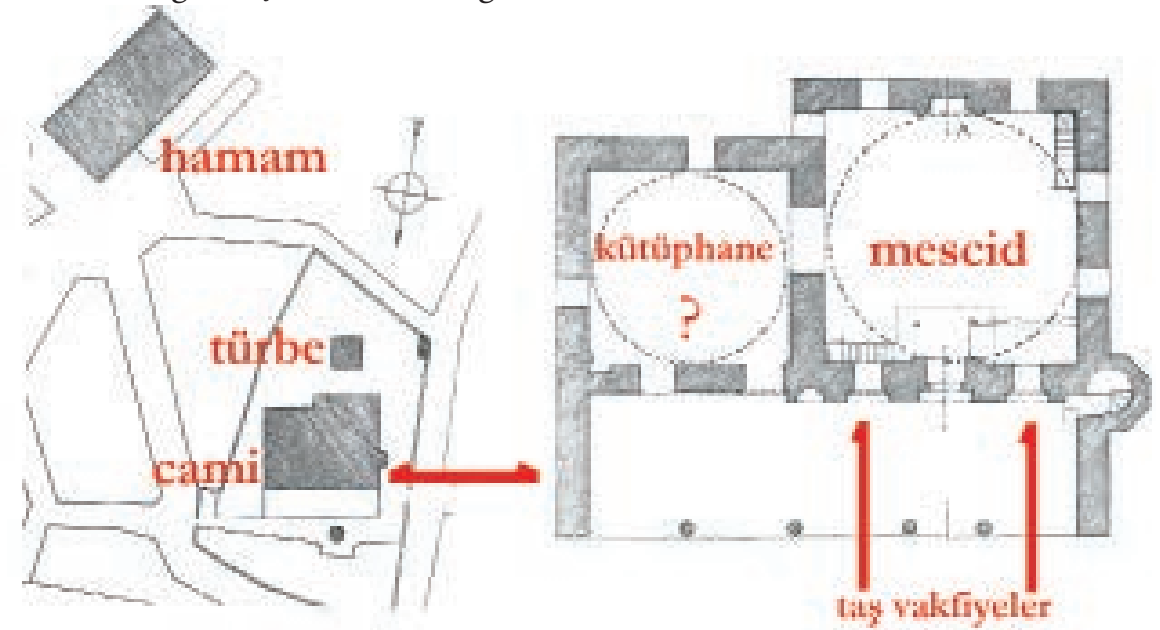

Figür 1. Bursa'da Umur Bey Külliyesi ve Umur Bey Camisi'nin planları (Gabriel, 2010'dan işlenerek).

24 Ayverdi, Osmanlı Mimârî̀sinde Çelebi ve II. Sultan Murad Devri, s. 344-345; Kepecioğlu, Bursa Kütüğü, s. 198-199; Ertan Daş, Erken Dönem Osmanlı Türbeleri (İstanbul: Gökkubbe Yayınları, 2007), s. 255-257; Ali Kılcı, "Erken Osmanlı (1299-1451) Baldaken Türbeleri”, Vakıflar Dergisi, XXIX (2005) s. 261-262; Gabriel, Bir Türk Başkenti Bursa, s. 146.

25 Ekrem Hakkı Ayverdi, Umur Bey'in vakfiyesinin 843/1440 tarihli kağıt üzerindeki bir nüshasından hareketle yapının taş vakfiyenin yerleştirilmesinden çok önce inşa edildiğini bildirerek yapıyı II. Murad dönemi içerisinde değerlendirmiştir [Ayverdi, Osmanlı Mimârîsinde Çelebi ve II. Sultan Murad Devri, s. 339-344]. Ayrıca bakınız; Albert Gabriel, Bir Türk Başkenti Bursa, s. 143-146; Kepecioğlu, Bursa Kütüğ̈̈, s. 196-197; Baykal, Bursa ve Anitlart, s. 134-135.

26 Yapı, 1855 depreminde zarar görmüştür. Depremde yıkılan kubbelerin yerine ahşap bir çatı yapılmıştır. 2013 yılındaki restorasyondan sonra kubbeler yeniden inşa edilmiştir. 
Umur Bey'in, taş vakfiyesi caminin kuzey duvarında yer almaktadır. Vakfiye metni, cümle kapısının sağ ve solundaki pencerelerin üzerinde iki farklı yazıt halinde bulunmaktadır (Figür 2). Mermere kabartma tekniği ile yapılmış yazıtların zemini yeşil, harfleri sarı renge boyanmıştır. Sağdaki yedi satırlık yazıt, 1.35 x 2.15 metre boyutlarında, içerik bakımından onu takip eden soldaki altı satılık yazıt ise 1.20 x 1.40 metre boyutlarındadır (Figür 3, 4).

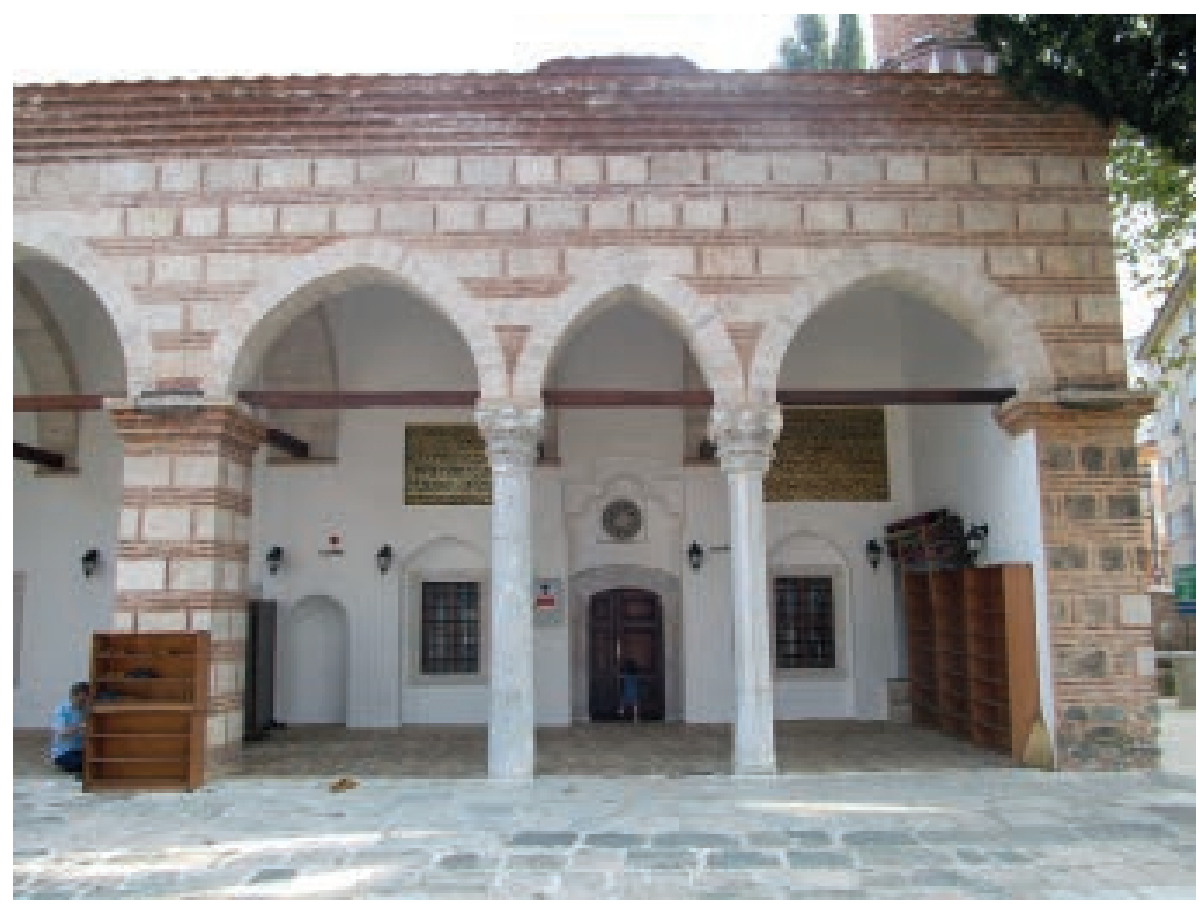

Figür 2. Bursa’da Umur Bey Camisi Son Cemaat yeri ve taş vakfiyeler.

Vakfiye Metni Transkripsiyonu;

(doğudaki yazıt)

“Bi'smi'llâhi'r-rahmâni'r-rahîm hamd (ve) senâ sâbitdir şol Allah'a ki bizî ḳurtarır rahmetiyle oddan ve dâhî salât ve ve's-selâm şol rasûlün üzerine olsun ki bize Allah buyrûgun yetişdirüb țogru yol gösterdi.

Bundan sonra bu târîhe nazar idene şöyle ma'lûm olsun ki ben ki Timurtâş og̉lî Umûr'um bu yerde hasbeten li'llâh bir câmi' binâ itdüm bu câmi' mesâliḥ̂ç̧ün yine yânında bir hamâm yâpup bu câmi'e vakf etdüm ve Tûz 


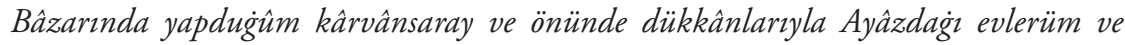

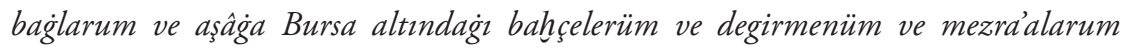
kâfirleriyle ve Bursa nâhiyyetindeki köylerüm kâfirleriyle ki Kelesân'dır ve Ak Köy'dür.

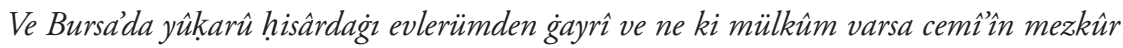
câmi'e vakf itdüm ve Înegöl nâhiyyetinde 'Îsâ vîranındaki degirmenüm bahçesiyle ve kâfirleriyle ve Engûriyye nâhiyyetinde Dâstârlî adlû̀ köyimî ve ol vilâyetde ne kadar mezra'alarum

Varsa ve Tekûr Bınârindaki üç hissem ki benimdir ve bağlarum ve bahcelerüm ve ekin yerlerüm ve kâfirlerüm mezkûrları bu câmi'e vakf itdüm ve kitâblarum tafsîlle vakf itdüm ammâ câmi'den țaşra çıkmaya ve Bîrg்ama'da hasbeten li'llâh bir medrese yâpdım ve yânında bir hamâm yâpup ol câmi'e vakf itdüm.

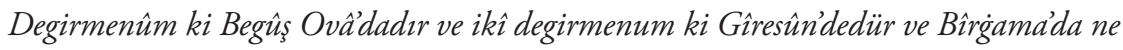
kadar dükkânlarum ve dükkân yerlerüm varsa ve bir ciftlik ki Ayvadogilu’ndan aldum

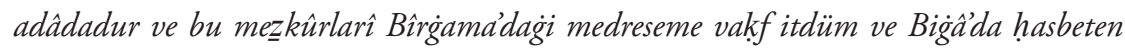
li'llâh bir câmi yâpdum yânında bir hamâm yâpup ol câmi'e vakf itdüm.

Ve Karahisâr'da bir câmi ve bir medrese yâpdum yânında bir hamâm ve kervânsarây yâpdum ve Sârûca Bınâr adlî köy ve Hûma'da bir celtûk dingî satûn aldım ve bu mezkûrları Karahisâr'dag̀z câmi'e ve bir medreseye vakf itdüm ve cemi'vakıflarım müseccel itdüm ve vakıfların gallâtından Gulyâdàġ kârvânsarây

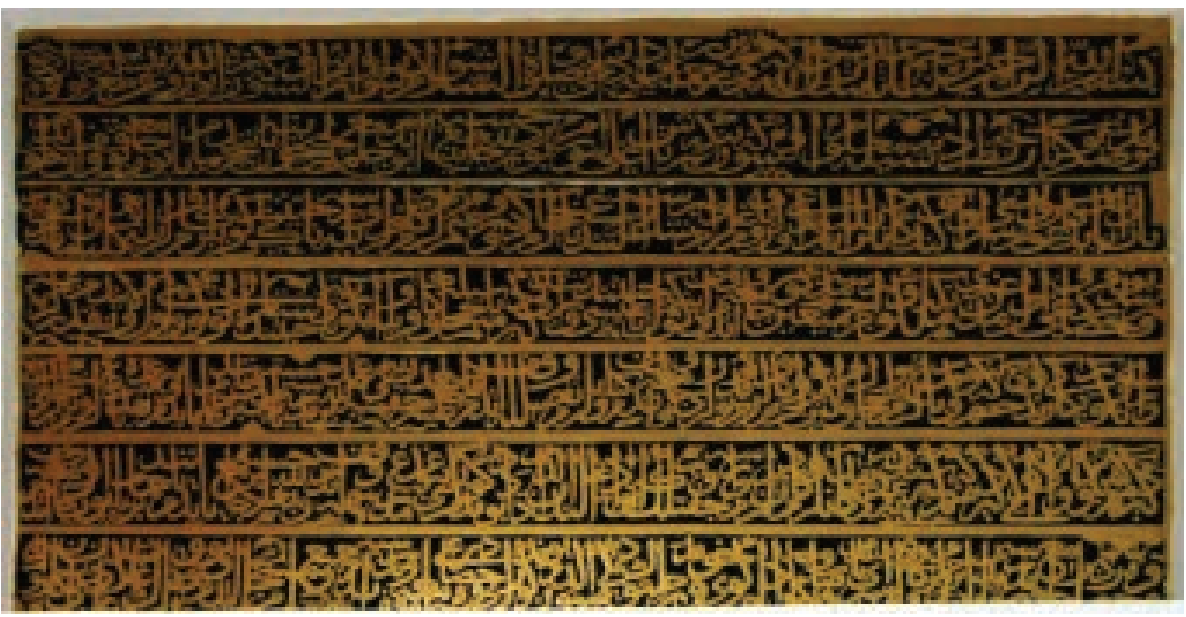

Figür 3. Doğudaki yazıt. 
(batıdaki yazıt)

ve yolundag் Köprücükler ve Derziler'deki kârvânsarây muhtâc oldug்unca meremmet ideler ve Karş̂u Savaklar adlû köyimi vakf-ı ebn itdüm ve Edirne’de hasbeten li'llâh bir mescid yâpdum ve anda yirler vârdur mukâtța'aya virülür

ve bầî̀m evlerûm ki anda vârdur yine Edirnéde yâpduġum mescide vakf itdüm ve bunlar küllîsi li'llâh bi'llâh olsun Allah rahmet itsûn ol kişiye ki bu târîhe nazar ide okuya vâkı r rûhuna du'â kıla Allahin làneti

ve melâikelerin la’neti ve peygamberlerin la’neti ol kişinin üzerine olsun kim bu vakıfların tebdîline ve taġyîrine kasd ide ve bunların fesâdına mübâş̧ir ola âmîn yâ Rabbe'l-âlemîn. Ve vakfnâmemdir

Kullarım benim zamânımda her birî ne yiyî geldilerse yine benden sonra anî yiyeler ve

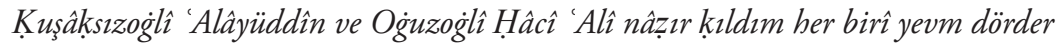

akce yiyeler ve bu târîh muharrem ayının âhirinde yazıldî ki sekiz yüz ellî tokuzuncî yıldır şekera'llâhü mesẩiyehûu evkấf-ı mezkîure üzere cibâyet

İtmekcûn memlîk Hoş̧adem bin 'Abdillâh ve dâhî oğlanlarî bunlara sa'yleri vakfa hıdmetlerî mukâbelesinde alà dört zer-i bunduklar ve yiyeler fe-kad cerâ ve hurrira fî̀ cümâe'l-âhir senete hamsin ve sittîne ve semânemae (865/1461).”27

27 Transkripsiyon: Tüfekçioğlu, Erken Dönem Osmanlı Mimarisinde Yazı s. 315-316. Okuma farklılıkları için: Ayverdi, Osmanlı Mimââîsinde Çelebi ve II. Sultan Murad Devri, s. 339340; Kepecioğlu, Bursa Kütü̆̆̈̈, s. 196-197; Ahmed Tevhid, "Bursa'da Umur Bey Cami Kitabesi”, s. 865-872; Baykal, Bursa ve Anıtlar, s. 199-201; Muallim Cevdet, "Bursa'da Gazi Umur Bey Camii Kitâbesi”, s. 258-261; Koyunluoğlu, İznik ve Bursa Tarihi, s. 178-180; Kunter, "Kitabelerimiz", s. 445-446; Türkiye'de Vakıf Abideler ve Eski Eserler, s. 145-147. Günümüz Türkçesiyle;

"Rahman ve rahim olan Allah'in adiyla; Hand ve sena bizi rahmetiyle atesten kurtaran Allah'a ve salat ve selam o peygamberin üzerine olsun ki bize Allah buyruğunu iletip doğru yolu gösterdi. Bu yazıtı okuyan olsun bilsin ki ben Timurtaş oğlu Umur'um; burada bir cami inşa ettim ve bu caminin faydalanmast için yanında bir hamam yapıp bu camiye vakfettim. Tuz Pazarinda yaptığım kervansaray; ve önündeki dükkanlarıyla Ayazdağın'daki evlerim ve bağlarım; ve aşăğ Bursa altındaki bahçelerim ve değirmenim; ve gayrimüslim halkıla birlikte Bursa çevresindeki mezralarım ve köylerim ki Kelesan ve Akköy'dür; ve Bursa yukarı hisardaki evlerim dışında ne mülküm varsa hepsini adi geçen camiye vakfettim. Inegöl çevresinde İsaviranindaki değirmenimi bahçesi ve gayrimüslim halkıyla; ve Ankara çevresindeki Dastarlı adlı köyümü ve o vilayetteki ne kadar mezram varsa; ve Tekfur Pınarindaki üç hissemi ve băglarımı, bahçelerimi, ekin yerlerimi ve gayrimüslim halkımı adı geçen camiye vakfettim. Ve kitaplarımı camiden dışar çıkarılmaması şartıyla vakfettim. Ve Bergama'da bir medrese ve yanında bir hamam yaptım, Bergama'da ne kadar bağım ve bahçem, değirmenim ki biri Begussova'da ve ikisi Giresin'dedir ve dükkanlarım ve dükkan yerlerim varsa hepsini ve Ayvazoğlu'ndan aldiğım adada bulunan çiftlik ile birlikte Bergama'da adi geçen medreseme vakfettim. Ve Biga'da bir cami yaptım yanında bir hamam yapıp o camiye vakfettim. Ve (Afyon) Karahisar'da bir cami ve bir medrese, yaninda 


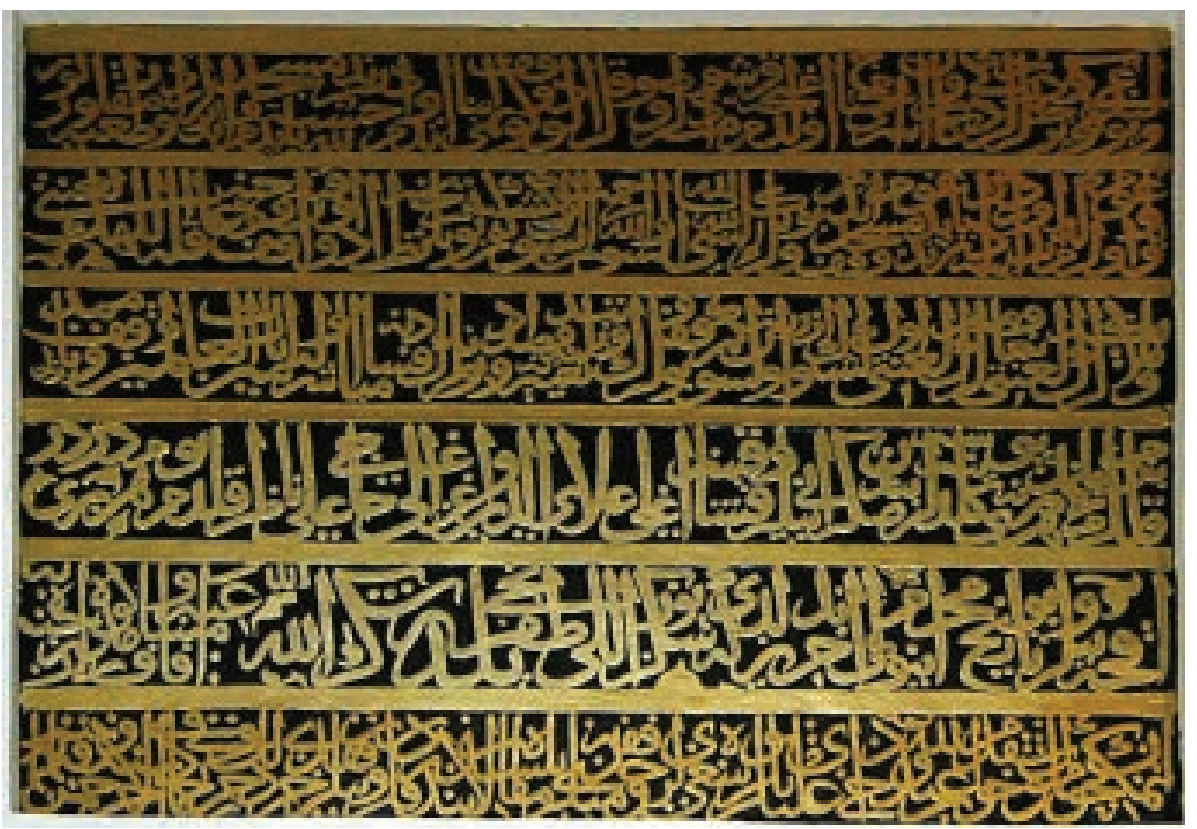

Figür 4. Batıdaki yazıt.

Taşınabilir nitelikteki [diğer bir deyişle kağıt üzerindeki] vakfiye metinleri, genellikle, sırasıyla; vakfiyeyi onaylayan kadı ya da kadıların imza ve mühürleri; vakıf sahibinin Allah'a hamd ve Peygamber'e dua ile vakfın kurmaktaki amacı; vakıf sahibinin adı ve nesebi ile tanıtımı; hayır işleri için inşa edilmiş yapılar ve işletilebilmesi amacıyla vakfedilen menkul ya da gayri-menkul gelir kaynakları; vakıf bütçesinin kullanımı ve vakıf personelinin maaş ve görevleri; vakfiye şartlarını

bir hamam ve kervansaray yaptım ve Sarıcapınar adlı köy ve Huma'da pirinç değirmeni satın aldım ve bu sözü edilenleri Karahisar'daki camiye ve medreseye vakfettim ve bütün vakıflarımı kaydettirdim/onaylattım. Ve vakıfların gelirlerinden Gulya'daki kervansaray ve yolundaki Köprücükler ve Terziler'deki kervansaray ihtiyaç olduğunca tamir edilsinler. Ve Karşısavaklar adlı köyümü evladıma vakfettim. Ve Edirne'de bir mescid yaptım ve oradaki kiraya verilen yerleri, bă̆ımı ve evlerimi Edirne’de yaptığım mescide vakfettim. Ve bunların hepsi yemin olsun ki, Allah, bu yazıta değer vererek okuyan ve vakfedenin ruhuna dua eden kişiye rahmet etsin; Allahin, meleklerin ve peygamberlerin laneti bu vakıfları değiştirmeye ve bozmaya kasteden ve bunların (vakıfların) kötülüğ̈̈ne yardımo olan kişinin üzerine olsun; amin, ya Alemlerin Rabbi; vakıfnamemdir. Kullarım (kölelerim) ben hayatta iken her biri ne yiyorsa, benden sonra da aynı şeyi yesinler; ve Kuşaksızoğlu Alaaddin ve Ŏguzoğlu Hacı Ali'yi herbirini dörder akçe yevmiye ile vakıflarıma nazır tayin ettim. Ve vakfiye metni 859 ynl Muharrem ayında (Aralık/Ocak, 1454/1455) yazıldı; vakıf gelirlerini toplamak için köle Abdullah oğlu Hoşkadem ve evlatların görevlendirdim. 865 yzlının Cemazeyilahir ayında (Mart/Nisan 1461).” 
kötü yönde değiştirecek, bozacaklara karşı vakıf sahibinin laneti ile devam ederek vakfiyenin tarihi ve şahitleri ile son bulmaktadır. ${ }^{28}$

Umur Bey'in taş vakfiyesi de aşağı yukarı bu genel kompozisyonu takip etmekle birlikte, 859/1454-1455 tarihli kağıt üzerindeki Arapça vakfiyenin, Umur Bey’in kendi ağzından yazılmış Türkçe bir özetidir. Vakfiyede, Umur Bey, Allah’a hamd ve peygambere dua ettikten sonra kendisini tanıtır ve vakıflarından bahseder. Ardından vakfın işleyişini engellemeye çalışacaklara lanet eder ve vakıf görevlilerinden bazılarından bahseder.

Taş vakfiyede, ağırlıklı olarak Bursa’daki vakıfların üzerinde durulur. Bununla birlikte, 859/1454-1455 tarihli vakfiyeden farklı olarak Edirne'de bir mescid ve vakıflarından ilk defa taş vakfiyede söz edilir. ${ }^{29}$ Öte yandan, Arapça vakfiyede adı geçen ancak nereye konulacağ 1 açıkça belirtilmeyen kitapların caminin içinde bulunduğu da taş vakfiyeden anlaşılmaktadır. ${ }^{30}$

Anadolu Türk mimarisinde yaygın olmayan taş vakfiye tercihinde Umur Bey'e ilham verecek çok fazla örnek bulunduğu söylenemez. ${ }^{31}$ Örneğin, Umur Bey Camisi'nden önce Osmanlı coğrafyasında inşa edilen yapılardan yalnızca üçü,

28 Bahaeddin Yediyıldız, XVIII. Yüzyılda Türkiye’de Vakıf Müessesesi: Bir Sosyal Tarih İncelemesi (Ankara: Türk Tarih Kurumu Yayınları, 2003), s. 4-5; Mehmet Şeker, "Vakfiyelerin Türk Kültürü Bakımından Özellikleri”, Ege Üniversitesi Edebiyat Fakültesi Tarih İncelemeleri Dergisi, VIII (1993), s. 4.

29 Bursa Vakfiyeleri, I, s. 480.

30 Erünsal, Türk Kütüphaneleri Tarihi II, s. 11.

31 Anadolu'da sınırlı sayıdaki birkaç örnek; Cantay, “Türklerde Vakıf ve Taş Vakfiyeler”, s. 147162; Abdülhamit Tüfekçioğlu, "Medeniyet Tarihimizde Taş Vakfiyeler", Yüzüncü Yıl Üniversitesi Sosyal Bilimler Enstitüsü Dergisi, I (2000), s. 33-34. İslam mimarisinde yazı kullanımının gelişim hakkında: Robert Hillenbrand, "Islamic Monumental Inscriptions Contexg tualised: Location, Content, Legibility and Aesthetics”, Beiträge zur Islamischen Kunst und Archäologie, vol. 3, ed. L. Korn, A. Heidenreich (Wiesbaden: Reichert Verlag, 2012), s. 13-38. Selçuklu ve Beylikler dönemi kitabeleri hakkındaki çalışmaları derleyen bir araştırma: Suat Kaymak, Türkiye Selçukluları ve Erken Beylikler Epigrafisine Giriş (1065-1350) (İstanbul: Arkeoloji ve Sanat Yayınları, 2013).

Taş vakfiyeye benzer bir uygulama Bizans kilise ve manastırlarında izlenebilmektedir. Birçok dini yapıda bağışçıya ait bir portre ve bağışlanan emlakı bildiren yazıtlara rastlanmaktadır. Çeşitli örnekler için: Sopia Kalopissi-Verti, "Church Inscriptions as Documents. Chrysobulls - Ecclesiastical Acts - Inventories - Donations- Wills”, $\triangle X A E, 24$ (2003), s. 79-88; Sopia Kalopissi-Verti, "Byzantine Dedicatory Inscriptions and Donor Portraits (7th-15th c.)", Inscriptions in Byzantium and Beyond, ed. Andreas Rhoby (Wien: Verlag der Österreichischen Akademie der Wissenschaften, 2015), s. 135-156. 
Mudurnu Yıldıım Hamamı (784/1382), ${ }^{32}$ Tokat Hamza Bey (Çekenli) Camisi $(815 / 1412)^{33}$ ve Amasya Bayezid Paşa İmareti (817-822/1414-1419) $)^{34}$ müstakil taş vakfiyelere sahiptir. Ankara Ahi Yakub Camisi (14. yy)'nde ise caminin vakıflarının işleyişine dair kısa bir gönderme inşa kitabesi içinde yer almıştır. ${ }^{35}$

Yıldırım Hamamı'nın vakıflarına ilişkin veriler, iki yazıt halinde erkekler bölümünün giriş kapısı üzerinde bulunur. ${ }^{36}$ Tokat Hamza Bey Camisi'nin vakfiye metni, kuzey cephede, giriş kapısının sağ tarafında, inşa kitabesi içinde yer almaktadır. ${ }^{37}$ Goodwin'in tabiriyle "gereğinden fazla bilgi sunan" bir yapı olan ve adeta banisinin sanat-mimari hamiliğine ilişkin özel ilgisini ilan eden Bayezid Paşa İmareti'nin vakıfları yapının son cemaat revağı üzerinde ve ayrıca yapıyı Yeşilırmak'ın karşı tarafına bağlayan köprünün ilerisinde kaya üzerine işlenmiştir. ${ }^{38}$

Öte yandan, Osmanlı baniler tarafından inşa edilmiş olmasalar da Anadolu'da bulunan sınırlı sayıdaki yapı; Sivas Burûciye Medresesi (670/1271) $)^{39}$ Erzurum'da Yakutiye Medresesi (710/1310) ${ }^{40}$ Seyit Gazi Külliyesi (14. yy), ${ }^{41}$ Konya'da Has

32 Ekrem Hakkı Ayverdi, İstanbul Mimâari Çăğnın Menşęi Osmanlı Mimarisinin ilk Devri Ertuğrul, Osman, Orhan Gaazîler Hüdavendigâr ve Yıldırım Bâyezid 630-805 (1230-1402) (İstanbul: İstanbul Fetih Cemiyeti, 1989a), s. 349-353;

33 Ayverdi, Osmanlı Mimârî̀sinde Çelebi ve II. Sultan Murad Devri, s. 201-203.

34 Ayverdi, Osmanlı Mimârî̀sinde Çelebi ve II. Sultan Murad Devri, s. 4-25; Albert Gabriel, Monuments Turcs D'Anatolie Tome Deuxième Amasya-Tokat-Sivas (Paris, 1934), s. 25-31; Doğan Kuban, Osmanl Mimarisi (İstanbul: YEM Yayınları, 2007), s. 108-110; Godfrey Goodwin, Osmanlı Mimarlı̆̆ı Tarihi, çev. Müfit Günay (İstanbul: Kabalcı Yayınları, 2012), s. 97-103; Mustafa Çağhan Keskin, "Syrian-Origin Architects Around Amasya Region in the Early 15th Century", A|Z ITU Journal of the Faculty of Architecture, 12/2 (2015), s. 19-33.

35 Tüfekçioğlu, Erken Dönem Osmanlı Mimarisinde Yazı, s. 75-76.

36 Tüfekçioğlu, Erken Dönem Osmanlı Mimarisinde Yazı, s. 51-53.

37 Tüfekçioğlu, Erken Dönem Osmanlı Mimarisinde Yazı, s. 102-104.

38 Son cemaat yerindeki ve kaya üzerindeki vakfiye metinleri Prof. Dr. Ali Yardım tarafından okunmuştur; Ali Yardım, Amasya Kaya Kitâbesi (Ankara: T. C. Amasya Valiliği Kültür Yayınları, 2004), s. 24-25, 123-126. Bayezid Paşa’nın entelektüel kişiliği ve sanat hamiliği hakkında: Mustafa Çağhan Keskin, "Bayezid Paşa: Vezir, Entelektüel, Sanat Hamisi”, Osmanlı Araştırmaları, XLVIII (2016), s. 1-37.

39 Tüfekçioğlu, "Medeniyet Tarihimizde Taş Vakfiyeler”, s. 35.

40 Hüseyin Yurttaş, Zeynep Köşklü, "Erzurum İli Vakfiyelerinde Taş Özetler”, Türk Dünyası, Dil ve Edebiyat Dergisi /Turkish World, Journal of Language and Litrature, 44 (2017), s. 355379; Rahmi Hüseyin Ünal, Erzurum Yakutiye Medresesi (Ankara: Kültür Bakanlığı Yayınları, 1993), s. 58-59; İbrahim Hakkı Konyal, Abideleri ve Kitabeleri ile Erzurum Tarihi (Erzurum: Ercan Matbaası, 1960), 324-325.

41 İlyas Küçükcan, Nacolea'dan Seyitgazi’ye Seyyid Battal Gazi ve Külliyesi (Eskişehir: Seyyid 
Bey Dar'ül Huffazı (824/1421), ${ }^{42}$ Karaman'da Karamanoğlu İbrahim Bey İmareti $(836 / 1432)^{43}$ ve Kütahya’da Germiyanoğlu II. Yakup Bey (Yakup Çelebi) İmareti (814/1411) ${ }^{44}$ müstakil taş vakfiyelere sahip olmalarıyla, Beyşehir Ulu Cami/Eşrefoğlu Camisi $(696 / 1297)^{45}$ ise inşa kitabesi içinde yer alan vakfiye göndermesi ile dikkat çeker.

Umur Bey, bu taş vakfiyelerin bazılarından haberdar olmalıdır. Örneğin, 834/1432 yılında Karakoyunlu İskender Mirza’nın Tokat çevresinden sürülmesi için Amasya valisi Yörgüç Paşa’nın yardımına gittiğinde Hamza Bey Camisi ve Bayezid Paşa İmareti'ni görmüş olması muhtemeldir. Ancak, Kütahya'da, Germiyanoğlu Yakup Bey ile birlikte bulunduğu yıllar göz önünde bulundurulduğunda, Yakup Bey'in taş vakfiyesini bilmemesi neredeyse olanaksızdır.

Diğer yandan, on altıncı yüzyıla kadar yapılarda yer alan yazıtlarda Türkçe’nin tercih edilmesi de yaygın değildir. Örneğin, Anadolu Selçuklu Dönemi kitabelerinde Arapça ve Farsça tercih edildiği görülürken, Türkçe bir kitabeye

Battal Gazi Vakfi, 2009).

42 İnşa kitabesinde, "buk'a” olarak tanımlanan yapı kare planlı, kubbe ile örtülü yapı mumyalık niteliğinde bir bodrum katına sahip olduğu için halk arasında türbe olarak kabul edilmektedir. Ernst Diez, Oktay Aslanapa, Mahmut Koman, Karaman Devri Sanatı (İstanbul: İstanbul Üniversitesi Edebiyat Fakültesi Yayınları, 1950), s. 121; Kamil Uğurlu, "Has Bey Dârülhuffâzı", TDV İslâm Ansiklopedisi (DİA), XVI (Ankara 1997), s. 272-273; Osman Nuri Dülgerler, Karamanoğulları Dönemi Mimarisi (Ankara: Türk Tarih Kurumu, 2006), s. 134-136. Yapıya ait olduğu düşünülen Türkçe vakfiye Konya Müzesi'nde yer almaktadır (env. No: 939).

43 Diez, Aslanapa, Koman, Karaman Devri Sanatı, s. 67-81; İbrahim Hakkı Konyalı, Abideleri ve Kitabeleri ile Karaman Tarihi Ermenek ve Mut Abideleri (İstanbul: Baha Matbaas1, 1967), s. 405-452; Ali Gülcan, Karamanoğlu II. İbrahim Bey ve İmareti Tarihçesi (Karaman: Doğuş Matbaası, 1983); Dülgerler, s. 116-119; Aynur Durukan, "İbrahim Bey İmareti ve Kümbeti”, TDV İslâm Ansiklopedisi (DİA), XXI (Ankara 2000), s. 287-290; Ayrıca bakınız; İsmail Hakkı Uzunçarşılı, "Karamanoğulları Devri Vesikalarından İbrahim Beyin Karaman İmareti Vakfiyesi”, Belleten, I/1 (1937), s. 56-164.

44 İmaret hakkında detaylı bilgi için: Ali Osman Uysal, Germiyanoğulları Beyliğinin Mimarî Eserleri (Ankara: Atatürk Kültür Merkezi Başkanlığı Yayınları, 2006), s. 125-140; Ayverdi, Osmanlı Mimârîsinde Çelebi ve II. Sultan Murad Devri, s. 516-518; Ara Altun, "Kütahya’nın Türk Devri Mimarisi-Bir Deneme”, Atatürk’ün Doğumunun 100. Yılına Armağan: Kütahya (İstanbul: ayrı basım, 1981-1982), s. 291-302. II. Yakup Bey hakkında; İsmail Hakkı Uzunçarşıl1, Anadolu Beylikleri ve Akkoyunlu, Karakoyunlu Devletleri (Ankara: Türk Tarih Kurumu Yayınları, 2003), s. 47-53.

45 Yusuf Akyurt, "Beyşehir Kitabeleri ve Eşrefoğulları Camii ve Türbesi”, Türk Arkeologya ve Etnografya Dergisi, IV (1940), s. 113-114. 
rastlanmamıştır. ${ }^{46}$ Öyle ki, Anadolu'da tespit edilebilen en erken tarihli Türkçe yazıt, Seyit Gazi Külliyesi'nde bulunan 770/1369 tarihli Germiyanoğlu hanedanından Kurt Abdal'ın taş vakfiyesidir. ${ }^{47}$ Umur Bey'in taş vakfiyesinden önce Osmanlı mimarisinde temsil bulan diğer Türkçe yazıtlar ise, 816/1413 tarihinde Amasyàya bağlı Gümüş kasabasında Halil Paşa tarafından inşa edilen medresenin batı ve güney cephesinde bulunan pencere alınlıklarında bulunan kitabeler ile 847/1443-1444 tarihli Uzunköprü’nün Uzunköprü yakasında bulunan çeşmenin üzerindeki inşa kitabesindeki iki satırdan ibarettir. ${ }^{48}$ Fatih Sultan Mehmed döneminden, diğer bir deyişle on beşinci yüzyılın ikinci yarısından itibaren Türkçe kitabelerin nispeten yaygınlaştığı gözlemlenir. ${ }^{49}$

46 Recep Gün, “Anadolu Selçuklu Mimarîsinde Yazı Kullanımı” (doktora tezi), Samsun: Ondokuz Mayıs Üniversitesi Sosyal Bilimler Enstitüsü, 1999, s. 164.

47 Mehmet Tütüncü, “Türkiye’de En Eski Türkçe Kitabe Eskişehir Seyitgazi İlçesinde Bulundu”, Düşünce ve Tarih Dergisi, 8 (2015), s. 16-23.

48 Tüfekçioğlu, Erken Dönem Osmanlı Mimarisinde Yazı, s. 126-129 ve 268-269.

49 Mustafakemalpaşa'da bulunan 867/1462 tarihli Hamza Bey Türbesi'nde giriş kapısının iki yanında bulunan yazıtlarda Türkçe vakfiye özetine yer verilmiştir [Tüfekçioğlu, Erken Dönem Osmanlı Mimarisinde Yazı, s. 323-324]. On altıncı yüzyılda İstanbul'daki üç yapı, vakfiye ve bağışlara ilişkin verileri detayları içeren hacimli yazıtlara sahiptir. İstinye’de 947/1540 yılında inşa edilmiş Neslişah Sultan Camisi'nin son cemaat yeri duvarında yer detaylı bir Türkçe taş vakfiye yer almaktadır [İ. Aydın Yüksel, Osmanlı Mimârîsinde Känûnî Sultan Süleyman Devri (926-974/1520-1566): İstanbul, VI (İstanbul: İstanbul Fetih Cemiyeti, 2004), s. 398-400]. Cafer Ağa Medresesi derslik kapısı üzerindeki 967/1560 tarihli Türkçe yazıt Sultan Süleyman’ın medreseye su bağışladığını bildiren bir fermanın özetini sunmaktadır [Yüksel, Osmanlı Mimârîsinde Kānûnî Sultan Süleyman Devri, s. 79-80]. Bali Paşa Camisi son cemaat yerinde mahfil girişi alınlığında yer alan 1000/1592 tarihli Arapça-Türkçe yazıt cami avlusuna bir şadırvan inşa eden Hassa suyolculardan Hızır Bey’in buraya vakfettiği gayrimülkü ilan eder [Tüfekçioğlu, "Medeniyet Tarihimizde Taş Vakfiyeler", s. 39; İ. Aydın Yüksel, Osmanlı Mimârîsinde II. Bâyezid, Yavuz Selim Devri (888-926/1481-1520), V (İstanbul: İstanbul Fetih Cemiyeti, 1983), s. 181-182. 
Gümüş ve Uzunköprü’de yer alan birer cümlelik Türkçe kitabelerin, hacim, içerik zenginliği, dil ve temsil bakımından çok daha bilinçli bir tercihi yansıtan Umur Bey taş vakfiyesi için örnek teşkil etmediği açıktır. Taş vakfiye, konu ve hacim itibariyle özellikle Seyit Gazi Külliyesi'nde Kurt Abdal, Has Bey Dar'ül Huffazı ve Yakup Çelebi İmareti'deki Türkçe taş vakfiyeler ile ilişkilendirilebilir. Vakıf sahibi okuyucuya bizzat seslenmediği, ancak ondan üçüncü tekil şahıs zamiriyle bahsedildiği taş vakfiye metinlerinin aksine, Umur Bey’in okuyucuya kendi ağzından hitap ettiği vakfiyesi, özellikle kendisi gibi muhatabına bizzat seslenen Yakup Bey’in vakfiyesini izlemektedir (Tablo 1, Figür 5). ${ }^{50}$

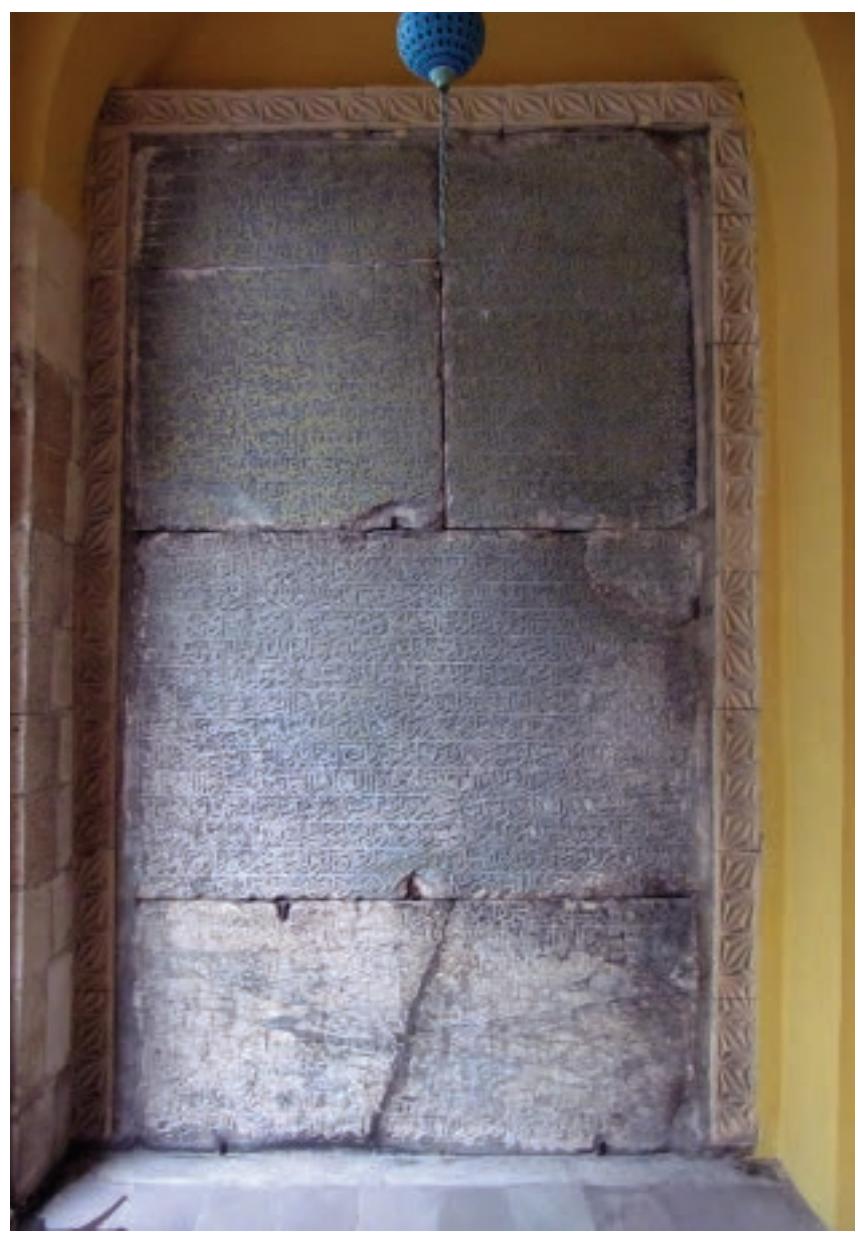

Figür 5. II. Yakup Bey’in taş vakfiyesi.

50 Yakup Bey’in taş vakfiye metni için bakınız: Uysal, Germiyanoğulları, s. 136-137, dn. 461. 
MUSTAFA ÇAĞHAN KESKİN

\begin{tabular}{|c|c|c|c|c|c|c|}
\hline $\begin{array}{l}\text { yap1nin } \\
\text { adi }\end{array}$ & yeri & $\begin{array}{l}\text { inşa } \\
\text { tarihi }\end{array}$ & $\begin{array}{l}\text { taş } \\
\text { vakfiye } \\
\text { tarihi }\end{array}$ & $\begin{array}{l}\text { yapidaki } \\
\text { konumu }\end{array}$ & $\begin{array}{l}\text { yaz1t } \\
\text { dili }\end{array}$ & $\begin{array}{l}\text { vakıf sahibini } \\
\text { niteleyen kişi } \\
\text { zamiri }\end{array}$ \\
\hline $\begin{array}{l}\text { Sivas Burûciye } \\
\text { Medresesi }\end{array}$ & Sivas & 1271 & 1271 & Avluda üç madalyon halinde & Arapça & $\begin{array}{l}\text { üçüncü } \\
\text { tekil şahıs }\end{array}$ \\
\hline $\begin{array}{l}\text { Beyşehir } \\
\text { Ulu Cami }\end{array}$ & $\begin{array}{l}\text { Beyşehir } \\
\text { (Konya) }\end{array}$ & 1297 & 1297 & giriş kap1sı (inşa kitabesi) & Arapça & $\begin{array}{l}\text { üçüncü } \\
\text { tekil şahıs }\end{array}$ \\
\hline $\begin{array}{l}\text { Yakutiye } \\
\text { Medresesi }\end{array}$ & Erzurum & 1310 & 1310 & $\begin{array}{l}\text { Mescit eyvanı doğu ve batı } \\
\text { duvarı üzerinde }\end{array}$ & Arapça & $\begin{array}{l}\text { üçüncü } \\
\text { tekil şahıs }\end{array}$ \\
\hline $\begin{array}{c}\text { Seyit Battal } \\
\text { Gazi Külliyesi }\end{array}$ & $\begin{array}{c}\text { Seyitgazi } \\
\text { (Eskişehir) }\end{array}$ & 14. yy & 1369 & $\begin{array}{l}\text { Battal Gazi Türbesi, türbedar } \\
\text { odası kapı kenarında }\end{array}$ & Türkçe & $\begin{array}{l}\text { üçüncü } \\
\text { tekil şahıs }\end{array}$ \\
\hline $\begin{array}{l}\text { Yildirim } \\
\text { Hamam }\end{array}$ & $\begin{array}{l}\text { Mudurnu } \\
\text { (Bolu) }\end{array}$ & 1382 & 1382 & giriş kapısı üzerinde & Arapça & $\begin{array}{l}\text { üçüncü } \\
\text { tekil şahıs }\end{array}$ \\
\hline $\begin{array}{l}\text { Ahi Yakub } \\
\text { Camisi }\end{array}$ & Ankara & 14. yy & 1392 & $\begin{array}{c}\text { giriş kapısı } \\
\text { (inşa kitabesi) }\end{array}$ & Arapça & $\begin{array}{l}\text { üçüncü } \\
\text { tekil şahıs }\end{array}$ \\
\hline $\begin{array}{l}\text { Hamza Bey } \\
\text { Camisi }\end{array}$ & Tokat & 1412 & 1412 & $\begin{array}{l}\text { giriş kapısı yanında } \\
\text { inşa kitabesi içinde }\end{array}$ & Arapça & $\begin{array}{l}\text { üçüncü } \\
\text { tekil şahıs }\end{array}$ \\
\hline $\begin{array}{l}\text { Yakup Çelebi } \\
\text { Imareti }\end{array}$ & Kütahya & 1411 & $\begin{array}{c}1414 \\
\text { sonras1 }\end{array}$ & $\begin{array}{l}\text { giriş revağı batı } \\
\text { duvarında }\end{array}$ & Türkçe & $\begin{array}{l}\text { birinci } \\
\text { tekil şahıs }\end{array}$ \\
\hline $\begin{array}{l}\text { Bayezid Paşa } \\
\text { Imareti }\end{array}$ & Amasya & 1414 & 1419 & $\begin{array}{l}\text { Son cemaat yeri revağ1 } \\
\text { üzerinde } \\
\text { / kaya üzerinde }\end{array}$ & Arapça & $\begin{array}{l}\text { üçüncü } \\
\text { tekil şahıs }\end{array}$ \\
\hline $\begin{array}{c}\text { Has Bey } \\
\text { Dar'ül-Hüffazı }\end{array}$ & Konya & 1421 & 1421 & $\begin{array}{c}\text { Konya Müzesi } \\
\text { (envanter no: 939) }\end{array}$ & Türkçe & $\begin{array}{l}\text { üçüncü } \\
\text { tekil şahıs }\end{array}$ \\
\hline $\begin{array}{l}\text { Ibrahim Bey } \\
\text { Imareti }\end{array}$ & Karaman & 1432 & 1432 & $\begin{array}{l}\text { yap1 içerisinde, tabhane giriş } \\
\text { kapıları alınlıklarında iki } \\
\text { parça halinde }\end{array}$ & Arapça & $\begin{array}{l}\text { üçüncü } \\
\text { tekil şahıs }\end{array}$ \\
\hline $\begin{array}{l}\text { Umur Bey } \\
\text { Camisi }\end{array}$ & Bursa & $\begin{array}{c}1440 \\
\text { öncesi }\end{array}$ & 1461 & $\begin{array}{c}\text { kuzey duvarında giriş kapısı } \\
\text { sağında ve soluna iki parça } \\
\text { halinde }\end{array}$ & Türkçe & $\begin{array}{c}\text { birinci } \\
\text { tekil şahıs }\end{array}$ \\
\hline
\end{tabular}

Tablo 1 - Umur Bey taş vakfiyesi öncesinde, on dört ve on beşinci yüzyılda Osmanlı coğrafyası ve çevresinde taş vakfiyeler ve özellikleri. 
Yakup Bey'in mensubu olduğu Germiyanoğlu hanedanı, kültür ve sanat hamiliği ile tanınmaktadır. Osmanlı klasik şiirinin temellerini atan, dönemin en önemli şairleri Germiyan saray ortamında ilgi görmüştür. ${ }^{51}$ Şeyhoğlu Mustafa, ${ }^{52}$ Şeyhî, ${ }^{53}$ Ahmed-i Dâî, ${ }^{54}$ ve ilk Osmanlı tarihini içeren İskendernâme’nin yazarı Ahmedî $\hat{\imath}^{55}$ telif ve çeviri eserleri ile Türkçe edebiyatın gelişmesine katkıda bulunmuştur. Germiyanoğlu saray ortamındaki kültür programı Yakup Bey’in taş vakfiyesindeki dil seçiminde etkili olmalıdır.

Umur Bey, pekala, uzun yıllar yakınında bulunduğu II. Yakup Bey’e öykünmüş ve inşa ettirdiği yapılardan en prestijlisi olan ve yanında defnedileceği caminin girişinde vakıflarını ilan ederek hayırseverliğini ölümsüzleştirmek istemiş

51 Halil İnalcık, Has-băggcede 'Ays u Tarab Nedîmler Şâîler Mutrîbler (İstanbul: Türkiye İş Bankası Yayınları, 2015), s. 97-148; Sooyong Kim, "Literary Culture in Fifteenth-Century Kütahya: A Preliminary Assessment", Islamic Literature and Intellectual Life in Fourteenthand Fifteenth-Century Anatolia, ed. A. C. S. Peacock, Sara Nur Yıldız (Würzburg: Ergon, 2016), s. 383-400.

52 Yakup Bey’in babası Süleyman Şah'ın sarayında nişancılık, defterdarlık ve musahiplik görevlerini üstelenen Şeyhoğlu, onun ölümünün ardından Yıldırım Bayezid'in ve daha sonra oğlu Emir Süleyman'ın hizmetine girmiş hizmetinde bulunmuştur. Eserleri arasında Hûrşid ü Ferahşâd, Marzubân-nâme, Kâbûs-nâme, Kenzül-Küberâ ve Mehekküll- ümerâ yer almaktadır. Ayrıca Taberî Tarihi'ni tercüme etmiştir [İnalcık, Has-băğçede 'Ayş u Tarab, s. 99101; Ahmet Atillâ Şentürk, Osmanlı Şiir Antolojisi (İstanbul: Yapı Kredi Yayınları, 2009), s. 1-2].

53 Tanınmış bir şair olmasının yanında aynı zamanda bir hekim de olan Mevlana Şeyhî, Germiyan ve Osmanlı saray ortamında tanınan biridir [İnalcık, Has-băģcede 'Ayş u Tarab, s. 101-106]. Şeyhî, ayrıca, II. Yakup Bey'in vakfiyesinin şahitleri arasındadır [Feridun Nâfiz Uzluk, "Germiyanoğlu Yakub II Bey’in Vakfiyesi”, Vakıflar Dergisi, VIII (Ankara 1969), s. 89].

54 Kütahya’nın Süleyman Şah’ın kızının çeyizi olarak Osmanlılara bırakıldığı dönemde kentin kadısı olan Ahmed-i Dâî, Emir Süleymani Çelebi Sultan Mehmed ve II. Murad'n hizmetinde bulunmuştur. Çengnâme, 'Ukûdül-cevâhir, Tezkiretül-evliyâ, Câmasb-nâme, Vasiyyet-i Nûşirevân adlı eserlerinin yanı sıra Attâr'ın Tezkiretül-evliya, Nâsır-1 Tusînin Sî Fasl fìt-takvim, Semerkandî’nin Tefsir'i gibi tercümeleri bulunmaktadır. Ahmed-i Dâî hakkında bir monografi: İsmail Hikmet Ertaylan, Ahmed-i Dẩi Hayatı ve Eserleri (İstanbul: İstanbul Üniversitesi Edebiyat Fakültesi, 1952). Ayrıca: İnalcık, Has-băğģede 'Ayş u Tarab, s. 106-112; Şentürk, Osmanl Şiir Antolojisi, s. 14-15.

55 İnalcık, Has-băğcede 'Ays u Tarab, s. 112-134; İsâmuddin Ebu'l-Hayr Ahmet Efendi Taşköprülüzâde, Osmanlı Bilginleri: eş-Şakâiku'n-Numâniyye fî ulemâi'd-Devleti'l Osmâniyye, çev. Muharrem Tan (İstanbul: İz Yayıncılık, 2007), s. 63; Franz Babinger, Osmanlı Tarih Yazarları ve Eserleri, çev. Coşkun Üçok (Ankara: T.C. Kültür Bakanlığı Yayınları, 2000), s. 12-13. 
olabilir. Bu bakımdan, taş vakfiyenin dili konusunda Umur Bey'e esin oluşturanın, öncelikle, yakından tanıdığı Yakup Bey’in vakfiyesi olduğu ileri sürülebilir.

Türkçe'nin tercih edilmiş olması aynı zamanda Umur Bey'in Türkçe'ye verdiği önemle de ilişkilidir. Çok geniş bir kitap koleksiyonuna sahip olan Umur Bey'in edebiyata ilgi duyan, entelektüel biri olduğu anlaşılmaktadır. Koleksiyonunda yer alan kitaplar arasında bazıları bizzat kendisi tarafından finanse edilen çok sayıda Türkçe telif ve çeviri eser bulunmaktadır. ${ }^{56}$

Umur Bey, dönemin ünlü entelektüelleriyle iletişim içindedir. Örneğin, on beşinci yüzyılda bir Osmanlı Tarihi kaleme alan Aşıkpaşazade'nin ravilerinden [sözlü kaynaklarından] biri de Umur Bey'dir. ${ }^{57}$ Bir dönem II. Yakup Bey'in himayesinde olan dönemin tanınmış isimlerinden Ahmed-i Dâî, daha sonra Umur Bey'in himayesine girmiş ve onun için Arapça ve Farsça'dan çeşitli tercümeler yapmıştır. ${ }^{58}$ Örneğin, dini ve dünyevi içerikli pek çok çeviri yapan Ahmed-i Dâî̀nin

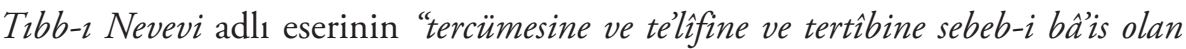
Umur bin Temürtaş-dur". ${ }^{59}$ Umur Bey'in Ahmed-i Dâî ile tanışıklığı olasılıkla Kütahyåda bulunduğu döneme dayanmaktadır.

Öte yandan, Umur Bey’in tıpkı Yakup Bey kendi ağzından hitap ediyor olması üzerinde durulması gereken başka bir konudur. Geleneksel uygulamada, Arapça, Farsça ya da Türkçe kitabelerde, bani veya vakıf sahibinden üçüncü tekil şahıs zamiriyle bahsedilir. Yalnızca, Yakup Bey ve Umur Bey’in taş vakfiyelerindeki tavır, metnin bizzat onlar tarafından dikte edildiğine işaret etmektedir. ${ }^{60}$

56 Umur Bey’in koleksiyonundaki Türkçe telif ve çeviri eserler için bakınız: Stanley, "The Books of Umur Bey”, s. 326-330; Cevat Sucu, "Rûm'da Kozmopolit Model Kurmak: Dāi ve 15. Yüzyıl Osmanlı Metin Kültürü” (yüksek lisans tezi), Ankara: İhsan Doğramacı Bilkent Üniversitesi Ekonomi ve Sosyal Bilimler Enstitüsü, 2017, s. 64-68.

57 Örneğin, Niğbolu Savaşı'nın Umur Bey'den dinlemiştir; "Kara Temürtaşoglı var-ıdı, aña Umur Beg dirler-idi. Bu gazâyı fakire ol habar virdi" [Aşı1k Paşazade, Osmanoğullarının Tarihi, s. 339]; tespit: Sucu, "Rûm’da Kozmopolit Model Kurmak", s. 65.

58 Sucu, "Rûm'da Kozmopolit Model Kurmak", s. 64-68; Stanley, “The Books of Umur Bey”, s. 324-328; Zeren Tanındı, "15th-Century Ottoman Manuscripts and Bindings in Bursa Libraries”, Islamic Art, IV (1991), s. 143.

59 Önder Çağıran, "Ahmed-i Dầ̂̀ Tıbb-ı Nebevî: İmlâ-Fonetik-Morfoloji-Karşılaştırmalı Metin-İndeks ve Sözlük” (doktora tezi), Malatya: İnönü Üniversitesi, 1992, s. 404 'ten alıntılayan Sucu, s. 65.

60 İstanbul'da, 1589 yılında tamamlanan bir Mimar Sinan yapısı olan Nişancı Mehmed Paşa Camisi'nin Arapça inşa kitabesinde de baninin kendi ağzından seslendiği görülmektedir (Kitabe metni için bakınız: Ali Rıza Özcan, İstanbul'un 100 Kitabesi (İstanbul: İstanbul 
Osmanlı yapılarında genellikle giriş kapısının üzerinde yapı hakkında bilgi veren bir inşa kitabesi bulunur. İnşa kitabeleri temelde; yapının işlevi, hükümdarlık unvanlarıyla birlikte dönemin sultanının ismi ve hükümdarlığının devamı için dua, baninin isim ve unvanları ile inşa tarihi ögelerinden oluşmaktadır. Buna bazen yapıda görev almış mimar ya da sanatçının ismi de eklenir. Umur Bey Camisi'nde ise bu pratiğin aksine bir inşa kitabesi bulunmaz. İnşa kitabesinin yerini bir vakfiye alır ve yapıya ilişkin bilgiler, yerleşik geleneğin aksine inşa kitabesi aracıllığıla değil, ancak taş vakfiye içinde ilan edilir. İnşa kitabesi yerine taş vakfiye tercihi yorumlanması gereken sıra dışı bir tutumdur.

İnşa kitabeleri [ya da bir onarım ardından kendine yer bulan tamir kitabeleri], içerik ve konumları bakımından, genellikle yapının hizmete açılışından önce yerlerini alırlar. Cami, 1440 tarihli vakıfnamede sözü edildiğine göre, bu tarihten daha önce inşa edilmiş, Umur Bey'in vakıfları ise 1454 yılında son halini almışıtır. Taş vakfiye ise yapının inşasından yaklaşık yirmi yıl, vakıfların son

Büyükşehir Belediyesi, 2011, s. 53). Kitabenin üzerinde Nişancı Mehmed Paşa’nın bizzat çektiği bir III. Murad Tuğrası yer almaktadır. Döneme ait başka bir yapıda yer almayan bu uygulamayı Gülru Necipoğlu baninin özel tercihine bağlamaktadır [Gülru Necipoğlu, The Age of Sinan: Architectural Culture in the Ottoman Empire (Princeton: Reaktion, 2005, s. 408-415)]. Paşanın bir biyografisini kaleme alan Atâî, onun görsel yeteneklerinin yanı sıra, sözel yeteneklere de sahip olduğunu bildirmekte ve Nāmî mahlasıyla şiirler yazdığını bildirmektedir [Nevizāde Atâî, "Hadāiku’l-hakā’ik fi tekmileti'ş-şakāik", Şakaik-i Nủmaniye ve Zeyilleri, II, haz. Abdülkadir Özcan (İstanbul: Çağrı Yayınları, 1989, s. 337’den naklen Necipoğlu, The Age of Sinan, s. 409]. Cami haziresinin giriş kapısı üzerinde "Merhûm ve mağfur sāhibu'l-hayratın nazm-1 şerîfleridir” başlığıyla, Paşanın Nāmî mahlası ile ölümünden sonra buraya konulması için kaleme aldığı üç beyitin yer aldığı bir kitabe bulunmaktadır [http://www.ottomaninscriptions.com/verse. aspx?.ref=list\&bid=2057\&hid=2715] . Tuğra, inşa kitabesi metni ve hazire girişindeki şiir bizzat paşanın kendi elinden ve kaleminden çımıştır. Nişancı Mehmed Paşa da Yakup Bey ve Umur bey gibi kendi adını ölümsüzleştirecek hayratının yazıt programının belirleyicisi olmayı tercih etmiştir. Baninin kitabeye bizzat müdahalede bulunduğu bazı örnekler biliniyor. Örneğin, 1894 depreminin ardından yenilenen Kapalıçarşı'nın Nuruosmaniye girişine anıtsal bir giriş kapısı inşa edilmiş ve tamirat sürecini anıtsallaştıracak bir kitabenin buraya konulmasına karar verilmiştir. Ancak, Serasker Mektupçusu Ahmed Muhtar Efendi’nin kaleme aldığı ve Ticaret ve Nafia Nezareti'nin II. Abdülhamid'e önerdiği tarih manzumesi sultan tarafından kabul edilmemiş, sultan günümüzde halen yerinde duran mensur metnin kitabede yer almasını emretmiştir [Yıldız Sadaret Resmi Maruzat Evrekı, 80/65 (1 Safer 1314/12 Temmuz 1896) ve Babıâli Evrak Odası 820/61490 (2 Safer 1314/13 Temmuz 1896)'dan naklen Sema Küçükalioğlu Özkılıç, 1894 Depremi ve İstanbul (İstanbul: Türkiye İş Bankası Yayınları, 2015), s. 227-228]. 
haliyle düzenlenmesinden ise yaklaşık yedi yıl sonra 1461 yılında yapıdaki yerini almıştır. Bu durum, taş vakfiyenin inşa kitabesinin bir muadili olmadığına işaret etmektedir.

Yapının herhangi bir yerinde temsil bulacak bir metnin boyut ve konumunda mimar ya da sanatçının tercihi etkili olabilir. Ancak, metnin içeriği, ilgili baninin onayından geçiyor olmalıdır; diğer bir deyişle baninin en azından inşa kitabesine kendisini niteleyecek sıfatlar konusunda müdahil olduğu düşünülebilir. Caminin inşasından yıllar sonra yapılacak böyle bir eklemenin ise bir sanatçı ya da mimar tarafından önerilmiş olmadığı anlaşılmaktadır. Kendi ağzından vakfiye metnini dikte etmiş olan ve ayrıca fazladan maliyetini karşılayacak olan Umur Bey, taş vakfiyenin caminin girişinde temsilindeki tek karar verici olmalıdır. Caminin tamamlanmasından yaklaşık yirmi yıl sonra aniden vakfiyesini taşa işletme ve ilan etme gereği duyan Umur Bey bir mesaj vermeyi amaçlıyor olmalıdır.

Günlük bir Türkçe'yi seçmiş olması, Umur Bey'in entelektüel kaygıları ve anadiline gösterdiği ilginin bir yansımasıdır. Ancak, vakfiye içeriği, Türkçe tercihinin özellikle verilmek istenen mesajın yapıya yolu düşen [okuma yazma bilen] herkes tarafından kolaylıkla anlaşılması yönünde ayrı bir motivasyona dayandığını düşündürüyor. Umur Bey’in taş vakfiyesi için ilham kaynağı olduğu anlaşılan Yakup Bey'in taş vakfiyesinde Türkçe'yi tercih etmesinin ardında halk tarafından kolayca anlaşılmasını arzuladığı sezinlenir. Yakup Bey, vakfiyesinde 814/1411 yılında tamamlanan yapının beş ay işledikten sonra Karamanoğulları’nın işgali sebebiyle iki buçuk yıl atıl kaldığını ve ancak Çelebi Sultan Mehmed'in onları Kütahyadan sürmesiyle tekrar hizmete girdiği belirterek, Osmanlı sultanına şükranlarını bildirir;

“...Ya’kub Beg bin Şah Süleyman hullide mülkuhu ilâ gayretz-zamân binâ itdi bu imâreti abiretiyşün Peygamber hicretinün sekiz yüz on dördünde temâm oldd. Kapust açıldn işledi beş ay işlendükten sonra Karaman-oğlu sebebile iki buçuk yıl mu'attal kaldı andan sonra Tengri Hudavendigarun devletin artursun geldi Karaman-oğlun sürdi bu yirleri hep girü ald bana virdi anun devletinde anun sadakasyla geri bu evün kapusı açıldo işlendi inşâallah anun devletinde devr-i kıyâmete dek kapusı baylmaya... ${ }^{\text {'61 }}$

Yakup Bey, taş vakfiyesinde vakfın iki buçuk yıl işletilememesine ve yapının atıl kalmasına neden olan Karamanoğulları'nı adeta şikayet etmektedir. Muhtaç

61 Uysal, Germiyanoğullar, s. 136, dn. 461. 
kimselerin hizmetine sunulan bir imaretin işleyişini durdurmakla suçlanan düşman (Karamanoğlu İbrahim Bey), bu yolla halkın gözünde itibarsızlaştırılarak, onun tarafından gelecek yeni bir işgal tehlikesine karşı halk başına gelebilecek muhtemel olumsuzluklar konusunda uyarılmaktadır. ${ }^{62}$

Umur Bey ise, taş vakfiyede Yakup Bey gibi vakfın işleyişiyle ya da yapıyla ilgili herhangi özel bir durumdan söz etmez, yalnızca vakıflarından bahseder. Taş vakfiyeyi düzenlettiği 1461 yılının Ağustos ayında vefat ettiği göz önünde bulundurularak, bir yandan öleceğini hissettiğini ve bu yazıtı isminin unutulmaması, hayratının ölümsüzleşmesi için bir araç, aynı zamanda bir vasiyetname şeklinde ele aldığı değerlendirilebilir. Diğer taraftan, dönemin siyasi gelişmeleri, Umur Bey’in başka kaygılarının olabileceğini düşündürmektedir.

Taş vakfiyenin düzenlendiği yıllarda, devlete ait toprakların gelirlerinin büyük çoğunluğu çeşitli hayır kuruluşlarına devredilmiş durumdadır. Akdağ’a göre devlet hizmetinde bulunanlar, görev sürelerinde kendilerine dirlik olarak verilen toprakları, kendi inşa ettirdikleri hayır kurumlarına, kendi öz mallarıymış gibi vakfettirmiş, genellikle, vakfın idaresini kendi ve sülalesine bırakmış, çoğu kez personeli de yakınlarından seçmiştir. ${ }^{63}$ Böylece, bir yandan hayır işlerken, bir yandan da vakıf bütçesinin bir kısmını nesilden nesile aktarılacak devamlı bir gelir kaynağı olarak ailelerine miras bırakmıştır. ${ }^{64}$

62 Kitabelerin günümüz ilan-bilgilendirme panoları gibi kullanıldığı bazı örnekler bulunmaktadır Örneğin, Ankara Kale Kapısı, Kırşehir Caca Bey Medresesi ve Niğde Sungur Bey Camisi'nde bulunan üç kitabe, kaldırılan vergilere ilişkin halkı bilgilendirmekte, aynı zamanda bu konuda verilen hükmü ölümsüzleştirmektedir [Walther Hinz, "Ortaçağ Yakın Şarkına Aid Vergi Kitabeleri”, Türkçe terc. Fikret Işıltan, Belleten, XIII/52 (1949), s. 771793 (Almanca özgün makale: "Steuerinschriften aus dem mittelalterlichen Vorderen Orient, Belleten, XIII/52 (1949), s. 745-769)]. Paul Wittek, “Ankara’da bir İlhanî Kitabesi” Türk Hukuk ve İktisat Tarihi Mecmuası, I (1931), s. 161-164; Cevat Hakkı Tarım, Kırşehir Tarihi (Kırşehir: Kırşehir Vilayet Matbaası, 1938), s. 62-65; Albert Gabriel Monuments Turcs D’Anatolie Kayseri-Niğde (Paris, 1934), s. 134.

63 Mustafa Akdağ, Türkiye’nin İktisadî ve İçtimầ Tarihi (İstanbul: Yapı Kredi Yayınları, 2010), s. 586.

64 Evlatlık vakıflar olarak adlandırılan bu tip vakıflar için: Ömer Lütfü Barkan, "İslâm - Türk Mülkiyet Hukuku Tatbikatının Osmanlı İmparatorluğunda Aldığı Şekiller I Şer’i Miras Hukuku ve Evlatlık Vakıflar”, İstanbul Üniversitesi Hukuk Fakültesi Mecmuası, VI/1 (1940), s. 155-181; Yediyıldız, XVIII. Yüzyılda Türkiye’de Vakıf Müessesesi, s. 17.

On dördüncü yüzyılın ünlü Arap düşünürü İbn Haldun (ö. 808/1406), Memlûk ortamından örnekleyerek evlatlık vakıf kurma motivasyonuna değinir. Ona göre, emirler sultanın hışmına uğrayıp mallarının müsadere edilmesinden çekindikleri için medrese, zaviye ve 
Umur Bey, vakıflarının idaresi için önce kendini, ölümünden sonra ise oğullarından en yetkini ve onun neslini mütevelli tayin etmiş ve vakfın giderlerinden arta kalan gelirinin 1/10'unu maaş olarak belirlemişsir. ${ }^{65}$ Başka bir deyişle, bu vakıf bir hayır kurumu olmasının yanı sıra Umur Bey'in çocuklarına, torunlarına ve onların nesillerine bıraktığı sürekli gelir sağlayan bir mirastır.

Vakfın gelir kaynakları arasında, kendi inşa ettirmiş ya da satın almış olduğu evler, dükkanlar, hamamlar, değirmenler ve bir han ile kendi mülkü olan bahçeler ve bağların yanı sıra, çeşitli köy ve mezralar yer alır. ${ }^{66}$ Vakıf gelirlerinin büyük bir kısmını Umur Bey'in tasarrufundaki köy ve mezralardan elde edilen gelirler oluşturmaktadır. Söz konusu köy ve mezraların vergisi, malikâne-divânî sistemine göre Umur Bey ve devlet hazinesi arasında paylaşılmaktadır. ${ }^{67}$

ribatlar inşa ederek gelir getiren akarlarını vakfedere ve kendi evlatlarını bu vakıflara mütevelli tayin ederek onlar için pay ayırırlar [İbn Haldun, Mukaddime, I-II, haz. Süleyman Uludağ (İstanbul: Dergah Yayınları, 2011), s. 781].

65 Vakfın mütevellisi öncelikle Umur Bey'in kendisi, sonra oğullarından en salihi ve onun nesli, sonra azatlı kölelerinden en salihi ve nesilleri, bunların nesli kesildiği takdirde kardeşleri Ali Bey ile Oruç Bey'in oğullarından en salihi ve nesli, bunların da nesli kesilir ise Bursa Kadısı'nın atayacağı biri olacaktır. Mütevelli, cami ve diğer vakıf mallarından artan gelirin 1/10'unu ücret olarak tasarruf eder. [VGMA, 591, 181-182; Bursa Vakfiyeleri - I, s. 479]. Türkçe vakfiye kitabesinde, vakıf mütevellisine ilişkin bir gönderme yer almamakla birlikte, nazır olarak görevlendirilen kölelerin isimleri açıkça belirtilmiştir.

66 Taş vakfiyede Bursa civarındaki Kelesân ve Ak Köy ile Ankara civarındaki Dastarlı adlı köy ve mezralardan bahsedilmektedir “...mezra'alarum kâfirleriyle ve Bursa nâhiyyetindeki köylerüm kâfirleriyle ki Kelesân'dır ve Ak Köy'dür... ve kâfirleriyle ve Engûriyye nâhiyyetinde Dâstârlî adlû köyimî ve ol vilâyetde ne kadar mezra'alarum varsa ... bu camie vakf itdüm". Vakfiyede; Akköy, Kelesân, Kara Gür (Düş Budak) köyüne yakın Ak Hisar’a bağlı bir mezra, Geyve'de Tekür Pınarı köyünün 3/8 hissesi, Ankara’da Dastarlı köyü, Aydıncık’a bağlı Sovuklar köyü ve buraya bağlı mezralar zikredilir [VGMA, 591, 181-182; Bursa Vakfiyeleri, I, s. 478]. 928/1521 ve 981/1573 tarihli tahrir kayıtlarında; Kelesan Köyü, Duşbudak köyü yakınlarında Hacı Bayram Mezrası ve Kara-Kilise civarında Umur Bey mezrası, Umur Bey vakıfları arasında yer almaktadır. Kelesan Köyü’nün (“šimdi Umur Bey tasarruf ider... asilda cami’ine vakf olmuş, vakıfnamesinde mukayyerdir") 4140 akçe; Hacı Bayram Mezrası ("Timurtaş oğlu Umur Beğ’in evvelden mülkü imiş, sonra Bursa'da olan camiine vakf etmiş, vakfiyet üzere tasarrufolunur, vakfiyesinde masturdur") 300 akçe, Umur Beğ mezrasının ise 100 akçe geliri vardır (Hüdavendigar Livası Tahrir Defterleri-I, haz. Ömer Lütfi Barkan, Enver Meriçli (Ankara: Türk Tarih Kurumu, 1988), s. 62, 258, 497.

67 Malikâne-divânî sistemi için bakınzı: Ömer Lütfi Barkan, "Türk-İslam Toprak Hukuku Tatbikatının Osmanlı İmparatorluğu'nda Aldığı Şekiller: Malikâne-divânî sistemi”, TürkHukuk ve İktisat Tarihi Mecmuası, 2 (1939), s. 119-184; Mehmet Genç, "Malikâne-divânî", TDV İslàm Ansiklopedisi (DİA), XXVII (İstanbul 2003), s. 518-519. 
Devlete ait gelirlerin vakıflar aracılığıyla özel kişilerin eline geçtiğini fark eden Fatih Sultan Mehmed, bir toprak reformu yaparak geliri vakıflara aktarılan arazi ve köylerin devletleştirilmesini amaçlamıştır. ${ }^{68}$ Bursa Şer'iyye kayıtlarında yer alan 885/1480 tarihli bir fermanda, vakıf sahiplerinin kişisel malı olan bağ, bahçe, değirmen, han, kervansaray, hamam gibi gayrimenkullerin gelirlerinin vakıflara aktarılması onaylanmakta ancak köy ve mezra gibi özünde devlete ait toprağın vakfedilmesi iptal edilmektedir:

“Mefahiri'l-kudat ve'l hükkâm ve mezâhirüssşserayi' ve'l ahkâm Beg sancağı kadılar dâme fadlubum, tevki-i refi' vâssl olıcak malum ola ki, şimdiki halde şäyle buyurdum $k i$, taht-r hükü̈metinizde olan evkaf-ı mensuhadan şol ki bağ ve bahçe ve değirmendir ve müsakkafattan evler ve dükkanlar ve kârbansaraylardır, bunlarn gibi sahipleri üzerine mukarrerdir. Anlarn gibi göresiz, eğer atabe-i ulyamdan takrir içün tecdid-i büküm almamış kimesne varsa gönderesiz ki gelüp kapımdan tecdid-i hükm alalar.

68 Ömer Lütfi Barkan, “Türkiye’de Toprak Meselesinin Tarihi Esasları”, Ömer Lütfi Barkan, Türkiye’de Toprak Meselesi: Toplu Eserler 1 (İstanbul: Gözlem Yayınları, 1980a), s. 125-149; “Türk-İslam Toprak Hukuku Tatbikatının Osmanlı İmparatorluğu’nda Aldığı Şekiller: Mülk Topraklar ve Sultanların Temlik Hakkı”, Ömer Lütfi Barkan, Türkiye’de Toprak Meselesi: Toplu Eserler 1 (İstanbul: Gözlem Yayınları, 1980b), s. 231-247; “Türk-İslam Toprak Hukuku Tatbikatının Osmanlı İmparatorluğu’nda Aldığı Şekiller: İmparatorluk Devrinde Toprak Mülk ve Vakıflarının Hususiyeti”, Ömer Lütfi Barkan, Türkiye'de Toprak Meselesi: Toplu Eserler 1 (İstanbul: Gözlem Yayınları, 1980c), 249-280; Bistra Civetkova, "Sur certaines reformes du régime foncièr au temps de Mehmed II.", Journal of the Economic and Social History of the Orient, 6 (1963), s. 104-120; Nicoara Beldiceanu, "Recherches sur la réforme foncière de Mehmed II.", Acta Historica, IV (1965), s. 27-39; Vera Moutafchieva, Agrarian Relations in the Ottoman Empire in the 15th and 16th Centuries (New York: Colombia University Press, 1988), s. 61-137; Akdağ, Türkiye’nin İktisadî ve İctimâ̂ Tarihi, s. 590; Halil İnalcık, Devlet-i Aliyye Osmanlı İmparatorluğu Üzerine Araştırmalar - I (İstanbul: Türkiye İş Bankası Kültür Yayınları, 2009), s. 122; Yediyıldız, XVIII. Yüzyılda Türkiye’de Vakıf Müessesesi, s. 132; Oktay Özel: "Limits of the Almighty: Mehmed II's 'Land Reform' Revisited", Journal of the Economic and Social History of the Orient, 42/2 (1999), s. 226-246. Bizans ve Memlûk ortamındaki benzer müsadere ve kamulaştırma uygulamaları için; Peter Charanis, "Monastic Properties and the State in the Byzantine Empire", Dumborton Oaks Papers, VI (1948), s. 53-118; John W. Barker, Manuel II Palaeologus 1391-1425: A Study in Late Byzantine Statesmanship (New Brunswick New Jersey: Rutgers University Press, 1969), s. 17; Eleutheria Papagianni, "Legal Institutions and Practice in Matters of Ecclesiastical Property", The Economic History of Byzantium From the Seventh through the Fifteenth Century, vol. 1, ed. Angeliki E. Laiou (Washington, D.C.: Dumberton Oaks, 2002), s. 1037-1047. Memlûk ortamından örnekler: Bethany J. Walker, "Popular responses to mamluk fiscal reforms in Syria”, Bulletin D'études Orientales, LVIII (2009), s. 51-68. 
Bunların maadası köylerden ve yerlerden fi'l cümle aksamı akarattan ne varsa bunlardan ekseriya mensubtur..." ${ }^{69}$

Bu ferman 885/1480 tarihli olsa da, toprak reformuna ilişkin ilk girişimler 863/1459 yılında, yani Umur Bey'in taş vakfiyesi düzenletmesinden iki yıl kadar önce, başlamış, ${ }^{70}$ Tursun Bey'in bildirdiğine göre, vakıfların tasarrufunda olan yirmi binden fazla köy ve mezraya devlet tarafından el konulmuştur. ${ }^{71} \mathrm{Bu}$ girişim, özellikle büyük araziler üzerinde tasarrufu bulunan köklü aileler tarafından tepkiyle karşılanmış, nitekim II. Bayezid saltanatının ilk aylarında bu uygulamadan vazgeçilmiştir. ${ }^{72}$

69 Halil İnalcık, "Bursa Şer'iyye Sicillerinde Fatih Sultan Mehmed'in Fermanları”, Belleten, XI/44 (Ankara 1947), s. 702-703; Ahmed Akgündüz, Osmanlı Kanunnâmeleri ve Hukukî Tahlilleri. 1. Kitap: Osmanl Hukukuna Giriş ve Fatih Devri Kanunnâmeleri (İstanbul: FEY Vakfi, 1990), s. 584.

Karamannâme yazarı Şikârî, Larende’yi (günümüz: Karaman) fetheden Gedik Ahmed Paşa'nın kale inşa etmek için Karamanoğlu eliti tarafından inşa edilen altı cami, dört medrese ve otuz üç mescidi yıktırdığını bildirmektedir;

"Osmanoğlu Sultan Mehemmed İstanbul'u kâfir elinden alduğu zamânda, yedi ynl sonra Gedük Ahmed Pâşâya emr edüb Lârende’ye gönderdi. Gedük gelüb altı yzl sefer edüb âhir Lârendèyi Karamanoğlu Kasım Begin elinden alub sarâyı yerine hisâr yapub nekadar 'azîm binâ var ise yıkub hisâra harc eyledi. 'Alâüddin yapduğu câmi'yi yıkub andan gayri beş câmi' dört medrese otuz üç vakt mescidi (...) yıkıb hisâra harc eyledi"

[Şikârî, Karamannâme (Zamanın Kahraman Karamanîler'in Taribi), haz. Metin Sözen, Necdet Sakaoğlu (İstanbul: Karaman Valiliği-Karaman Belediyesi Yayını, 2005), s. 181]. Gedik Ahmed Paşa'nın sözü edilen dini yapıları yıktırması şüphesiz sultanın bilgisi dahilindedir. Yalnızca, kale inşa etmek için bu kadar yapının ortadan kaldırılmış olmadı̆̆ ortadadır. Yıkılan cami, medrese, türbe, mescid gibi yapıların her birinin ayrı vakıfları bulunmaktaydı. Yapıların ortadan kalkması aynı zamanda bunların vakıflarının da ortadan kalkması anlamına gelmekteydi. Böylece, Karamanoğlu eliti tarafından vakfedilen bu yapılara vakfedilen arazi, vakıflar ortadan kalktığ 1 için devletin tasarrufuna geçmiştir. Kısaca, sultan, Karamanoğlu vakıflarına müdahale etmemiş ancak vakıfları dolaylı yoldan ortadan kaldırmıştır. Gedik Ahmed Paşa’nın yıktırdığı cami, medrese, mescid, türbe gibi yapıların Karaman Kalesi'nin inşasında kullanılmasıyla ilgili bakınız: Konyalı, Abideleri ve Kitabeleri ile Karaman Tarihi, s. 162-178.

70 Civetkova, "Sur certaines reformes du régime foncièr au temps de Mehmed II.", s. 108-109; Özel, "Limits of the Almighty", s. 233.

71 “...yigirmi bin artuk kurâ vü mezâri' var ola ki ashâb-ı emlâk ü evkâf tasarrufindan intizâa olunmışt, kemâl-i merâhimiyle yine ehline ihsan eyledi" [Tursun Bey, Târih-i Ebül-feth, haz. Mertol Tulum (İstanbul: İstanbul Fetih Cemiyeti 1977), s. 22].

72 Özel, "Limits of the Almighty”, s. 227. Aşı k Paşazade, bu uygulamanın asıl sorumlu olarak gördüğü Nişancı Karamanî Mehmed Paşàyı sert sözlerle eleştirir, “Āsâr-ı Nişâncı Paşa kim 
Umur Bey, taş vakfiyede, vakfın işleyişini aksatacak herhangi bir müdahalede bulunacak kişiye açıkça lanet etmektedir; "...Allah’in láneti ve melâikelerin la’neti ve peygamberlerin làneti ol kişinin üzerine olsun kim bu vakıflarm tebdîline ve taġyîrine kasd ide ve bunlarn fesâdina mübâşir ola âmîn yâ Rabbèl-âlemîn ve vakfnâmemdir..."Bu lanetin muhatabı toprak reformuyla vakıf gelirlerinin büyük kısmını oluşturan köy ve mezraların gelirlerini devlete aktaracak olan Fatih Sultan Mehmed olabilir. Umur Bey, 863/1459 yılından itibaren ilk adımları atılan toprak reformundan kendi vakfının da etkileneceğini önceden sezerek, vakfettiği köy ve mezralara devlet tarafından el konulması halinde vakfın işleyişinde yaşanacak sıkıntılara karşın 859/1454 yılında vakfettiği köy ve mezraları, 865/1461 yılında adını taşıyan caminin girişine yerleştirdiği gündelik Türkçe bir yazıt aracılı̆̆ı ile ilan ederek tepkisini ortaya koymuş gibi görülmektedir.

Umur Bey'in taş vakfiyesi, Osmanlı kültür ortamında, sıradan halkın konuştuğu gündelik Türkçe’nin, kağıt üzerinden çıkarak kamusal alanda temsil bulduğu ilk ciddi girişimlerden biridir. Umur Bey’e bu konuda esin kaynağı olan ve cesaret veren, uzun süre yanında bulunduğu ve yakından tanıdığı, kendisi gibi yönetici elitin entelektüel bir üyesi olan Germiyanoğlu II. Yakup Bey’in Türkçe vakfiyesi olmuştur. Türkçe tercihi, Fatih Sultan Mehmed döneminden itibaren siyasi nüfuzunu gün geçtikçe yitiren Türk kökenli elitin bir üyesi olan Umur Bey’in anadiline verdiği önemi göstermesinin yanı sıra okuma bilen halkın büyük çoğunluğunun Arapçayı anlamadığı göz önünde bulundurularak metnin kolayca anlaşılması kaygısında olduğunu düşündürmektedir. Vakfiyenin Biga, Bergama, Karahisar ya da Edirne'de inşa ettirdiği daha az dikkat çekici yapılar yerine Osmanlı'nın kadim başkenti Bursa'da, anıtsal özellikleri ön planda olan bir yapıda temsil edilmesi de, daha kalabalık bir kitleye ulaşma çabasının bir ayağı olarak değerlendirilebilir. İçerik, Fatih Sultan Mehmed'in yürürlüğe koyduğu, vakfin temel gelir kaynakları olan köy ve mezraların durumunu doğrudan etkileyecek olan toprak reformuna karşı olası tepkiyi yansıtmaktadır.

o nesl-i bühtândur. Allah'un kullarınun mâlına ve kanına ve ırzına tama' itmişdi. Ve her kanda kim mühmel işler var-ısa anun ihdasıdır. Vilâyet-i 'Osmânda ne kadar kim şser'-i Muhammedilen olmıs vakıflar ve mülkler var-ısa cemi isini bozdı. Hâsılların pâdişâhun hazinesine getürdi.” [Aşı1k Paşazade, Osmanoğullarının Taribi, s. 479]. 
Umur Bey Taş Vakfiyesi: Esin ve İçerik Üzerine Bir Değerlendirme

Öz — Umur Bey'in Bursa'da inşa ettiği camide yer alan taş vakfiye, Osmanlı kültür ortamında, sıradan halkın konuştuğu gündelik Türkçe’nin, kağı üzerinden çıkarak kamusal alanda temsil bulduğu ilk ciddi girişimlerden biridir. Umur Bey’e bu konuda esin kaynağı olan ve cesaret veren, uzun süre yanında bulunduğu ve yakından tanıdığı, kendisi gibi yönetici elitin entelektüel bir üyesi olan Germiyanoğlu II. Yakup Bey'in Kütahya'da yer alan Türkçe taş vakfiyesi olmuştur. Türkçe tercihi, Osmanlı bürokrasisinde nüfuzunu gün geçtikçe yitiren Türk kökenli elitin bir üyesi olan Umur Bey’in anadiline verdiği önemi göstermesinin yanı sıra okuma bilen halkın büyük çoğunluğunun Arapçayı anlamadığı göz önünde bulundurularak metnin kolayca anlaşılması kaygısında olduğuna işaret eder. Vakfiyenin kamusal alanda ilanı, Fatih Sultan Mehmed'in vakıfların temel gelir kaynakları olan köy ve mezraların devletleştirilmesini öngören toprak reformu ile zamanlama bakımından örtüşmektedir. Bu durum, Umur Bey’in vakfettiği araziyi kamuya ilan ederek toprak reformuna karşı bir tepki ortaya koyduğunu düşündürmektedir.

Anahtar kelimeler: Osmanlı Mimarisi, Osmanlı Kitabeleri, Taş Vakfiye, Umur Bey, Bursa.

\section{Bibliyografya}

Ahmed Bâdî Efendi: Riyâz-ı Belde-i Edirne: 20. Yüzyıla Kadar Osmanlı Edirne’si, haz. Niyazi Adıgüzel, Raşit Gündoğdu, İstanbul: Trakya Üniversitesi 2014.

Ahmed Tevhid (Ulusoy): "Bursa'da Umur Bey Cami Kitabesi”, Tarih-i Osmanî Encümeni Mecmuasi, 14 (1328), s. 865-872.

Akdağ, Mustafa: Türkiyénin İktisadî ve İçtimâ̂ Taribi, İstanbul: Yapı Kredi Yayınları 2010.

Akgündüz, Ahmed: Osmanlı Kanunnâmeleri ve Hukukî Tahlilleri. 1. Kitap: Osmanlı Hukukuna Giriş ve Fatih Devri Kanunnâmeleri, İstanbul: FEY Vakfı 1990.

Akyurt, Yusuf: "Beyşehir Kitabeleri ve Eşrefoğulları Camii ve Türbesi”, Türk Arkeologya ve Etnografya Dergisi, IV (1940), s. 91-129.

Altun, Ara: “Kütahya’nın Türk Devri Mimarisi-Bir Deneme”, Atatürk’ün Doğumunun 100. Yilına Armă̆an: Kütahya, İstanbul: ayrı basım, 1981-1982.

Aşık Paşazade: Osmanoğullarının Tarihi: Tevârih-i Al-i Osmân, haz. K. Kemal Yavuz, M. A. Yekta Saraç, İstanbul: Gökkube Yayınları 2010.

Atâî, Nevizāde: Hadäiku'l-hakäì fi tekmiletişs-şakäik, Şakaik-i Nümaniye ve Zeyilleri, II, haz. Abdülkadir Özcan, İstanbul: Çağrı Yayınları 1989.

Ayverdi, Ekrem Hakkı: İstanbul Mimâri Çağının Menşe’i Osmanlı Mimarisinin ilk Devri Ertuğrul, Osman, Orhan Gaazîler Hüdavendigâr ve Yildırım Bâyezid 630-805 (12301402), İstanbul: İstanbul Fetih Cemiyeti 1989. 
Ayverdi, Ekrem Hakkı: Osmanl Mimarisinde Çelebi ve II. Sultan Murad Devri 806-855 (1403-1451), İstanbul: İstanbul Fetih Cemiyeti Yayınları 1989.

Babinger, Franz: Osmanlı Tarih Yazarları ve Eserleri, çev. Coşkun Üçok, Ankara: Kültür Bakanlığı Yayınları 1992.

Barkan, Ömer Lütfi, “Türk-İslam Toprak Hukuku Tatbikatının Osmanlı İmparatorluğu’nda Aldığı Şekiller: Malikâne-divânî sistemi”, Türk-Hukuk ve İktisat Tarihi Mecmuası, 2 (1939), s. 119-184.

Barkan, Ömer Lütfi: "İslâm - Türk Mülkiyet Hukuku Tatbikatının Osmanlı İmparatorluğunda Aldığı Şekiller I Şer’i Miras Hukuku ve Evlatlık Vakıflar”. İstanbul Üniversitesi Hukuk Fakültesi Mecmuası, VI/1 (1940), s. 155-181.

Barkan, Ömer Lütfi: “Türkiye’de Toprak Meselesinin Tarihi Esasları”, Ömer Lütfü Barkan, Türkiye'de Toprak Meselesi: Toplu Eserler 1, İstanbul: Gözlem Yayınları 1980a, s. $125-149$.

Barkan, Ömer Lütfi: “Türk-İslam Toprak Hukuku Tatbikatının Osmanlı İmparatorluğu’nda Aldığı Şekiller: Mülk Topraklar ve Sultanların Temlik Hakkı”, Ömer Lütfü Barkan, Türkiye'de Toprak Meselesi: Toplu Eserler 1, İstanbul: Gözlem Yayınları 1980b, s. 231247.

Barkan, Ömer Lütfi: “Türk-İslam Toprak Hukuku Tatbikatının Osmanlı İmparatorluğu’nda Aldığı Şekiller: İmparatorluk Devrinde Toprak Mülk ve Vakıflarının Hususiyeti”, Ömer Lütfü Barkan, Türkiye'de Toprak Meselesi: Toplu Eserler 1, İstanbul: Gözlem Yayınları 1980c, s. 249-280.

Barker, John W.: Manuel II Palaeologus 1391-1425: A Study in Late Byzantine Statesmanship, New Brunswick New Jersey: Rutgers University Press 1969.

Baykal, Kazım: Bursa ve Anttlar, Bursa: Hakiyet Tesisleri 1993.

Beldiceanu, Nicoara: "Recherches sur la réforme foncière de Mehmed II.", Acta Historica, IV (1965), s. 27-39.

Bilge, Mustafa: İlk Osmanlı Medreseleri, İstanbul: İstanbul Üniversitesi Edebiyat Fakültesi Yayınları 1984.

Bilmiş, Hüseyin Gürsel: Bursa İnebey Kütüphanesindeki Ortaçă̆ İlam Ciltlerinin (13-14. Yüzyıl) Cilt Sanatı Açısından Değerlendirilmesi, (Yayımlanmamış Yüksek Lisans Tezi) İstanbul: Mimar Sinan Güzel Sanatlar Üniversitesi Sosyal Bilimler Enstitüsü, 2013. Bursa Vakfiyeleri, I, haz. Hasan Basri Öcalan, Sezai Sevim, Doğan Yavaş, Bursa: Bursa Büyükşehir Belediyesi Kültür A.Ş. 2013.

Cantay, Gönül: “Türklerde Vakıf ve Taş Vakfiyeler”, Vakıf Kültür Varlı̆̆ının Korunması, Yaşatılması ve Bu Amaçla Malî Kaynak Sağlanması Semineri Bildiriler, Ankara: Vakıflar Genel Müdürlüğü Yayınları 1994, s. 147-162. 
Charanis, Peter: "Monastic Properties and the State in the Byzantine Empire", Dumborton Oaks Papers, VI (1948), s. 53-118.

Civetkova, Bistra: "Sur certaines reformes du régime foncièr au temps de Mehmed II.", Journal of the Economic and Social History of the Orient, 6 (1963), s. 104-120.

Çağıran, Önder: Ahmed-i Dầ̂ Tıbb-ı Nebevî: Imlâ-Fonetik-Morfoloji-Karşılaştırmalı Metin-İndeks ve Sözlük (Yayımlanmamış Doktora Tezi), Malatya: İnönü Üniversitesi, 1992.

Daş, Ertan: Erken Dönem Osmanl Türbeleri, İstanbul: Gökkubbe Yayınları 2007.

Diez, Ernst, Oktay Aslanapa, Mahmut Koman: Karaman Devri Sanatı, İstanbul: İstanbul Üniversitesi Edebiyat Fakültesi Yayınları 1950.

Doukas, Mikhaèl: Tarih: Anadolu ve Rumeli (1326-1462), çev. Bilge Umar, İstanbul: Arkeoloji ve Sanat Yayınları 2008.

Durukan, Aynur: "İbrahim Bey İmareti ve Kümbeti”, TDV İslâm Ansiklopedisi (DİA), XXI (Ankara 2000), s. 287-290.

Dülgerler, Osman Nuri: Karamanoğulları Dönemi Mimarisi, Ankara: Türk Tarih Kurumu 2006.

Emecen, Feridun: "Timurtaş Paşa”, TDV İslâm Ansiklopedisi (DİA), XLI (Ankara 2012), s. $185-186$.

Ertaylan, İsmail Hikmet: Ahmed-i Dâi Hayatı ve Eserleri, İstanbul: İstanbul Üniversitesi Edebiyat Fakültesi 1952.

Erünsal, İsmail, E.: Türk Kütüphaneleri Tarihi II: Kuruluştan Tanzimat’a Kadar Osmanlı Vakıf Kütüphaneleri, Ankara: Atatürk Kültür Merkezi 1991.

Erünsal, İsmail E.: "Umur Bey Kütüphanesi”, TDV İslâm Ansiklopedisi (DİA), XLII (Ankara 2012), s. 159-160.

Gabriel, Albert: Monuments Turcs D'Anatolie Tome Deuxième Amasya-Tokat-Sivas, Paris, 1934.

Gabriel, Albert: Monuments Turcs D’Anatolie Kayseri-Niğde, Paris, 1934.

Gabriel, Albert: Bir Türk Başkenti Bursa, haz. Neslihan Er, Hamit Er, Aykut Kazancigil, Bursa: Osmangazi Belediyesi Yayınları 2010.

Genç, Mehmet: "Malikâne-divânî”, TDV İslâm Ansiklopedisi (DİA), XXVII (İstanbul 2003), s. 518-519.

Goodwin, Godfrey: Osmanlı Mimarlı̆̆g Tarihi, çev. Müfit Günay, İstanbul: Kabalcı Yayınları 2012.

Gülcan, Ali: Karamanoğlu II. İbrahim Bey ve İmareti Tarihçesi, Karaman: Doğuş Matbaası 1983. 
Gün, Recep: Anadolu Selçuklu Mimarîsinde Yazı Kullanımı (Yayımlanmamış Doktora Tezi), Samsun: Ondokuz Mayıs Üniversitesi Sosyal Bilimler Enstitüsü, 1999.

Hoca Sadeddin Efendi: Tâcü't Tevârih, II, haz. İsmet Parmaksızoğlu, İstanbul: Kültür Bakanlığı Yayınları 1992.

Hillenbrand, Robert: "Islamic Monumental Inscriptions Contextualised: Location, Content, Legibility and Aesthetics", Beiträge zur Islamischen Kunst und Archäologie, vol. 3, ed. L. Korn, A. Heidenreich, Wiesbaden: Reichert Verlag 2012, s. 13-38.

Hinz, Walther: "Ortaçağ Yakın Şarkına Aid Vergi Kitabeleri”, çev. Fikret Işıltan, Belleten, XIII/52 (1949), s. 771-793 [Almanca özgün makale: "Steuerinschriften aus dem mittelalterlichen Vorderen Orient, Belleten, XIII/52 (1949), s. 745-769].

Hüdavendigar Livası Tahrir Defterleri-I, haz. Ömer Lütfi Barkan, Enver Meriçli, Ankara: Türk Tarih Kurumu 1988.

İbn Haldun: Mukaddime, I-II, haz. Süleyman Uludağ, İstanbul: Dergah Yayınları 2011. İnalcık, Halil: "Bursa Şer'iyye Sicillerinde Fatih Sultan Mehmed'in Fermanları”, Bellten, XI/44 (1947), s. 693-708.

İnalcık, Halil: Devlet-i Aliyye: Osmanlı Imparatorluğu Üzerine Araştırmalar - I, İstanbul: Türkiye İş Bankası Kültür Yayınları 2009.

İnalcık, Halil: Has Bağçede Ays u Tarab: Nedimler, Şairler, Mutripler, İstanbul: Türkiye İş Bankası Kültür Yayınları 2015.

Kalopissi-Verti, Sopia: "Church Inscriptions as Documents. Chrysobulls - Ecclesiastical Acts - Inventories - Donations- Wills", $\triangle X A E, 24$ (2003), s. 79-88.

Kalopissi-Verti, Sopia: "Byzantine Dedicatory Inscriptions and Donor Portraits (7th-15th c.)", Inscriptions in Byzantium and Beyond, ed. Andreas Rhoby, Wien: Verlag der Österreichischen Akademie der Wissenschaften 2015, s. 135-156.

Kaymak, Suat: Türkiye Selçukluları ve Erken Beylikler Epigrafisine Giriş (1065-1350), İstanbul: Arkeoloji ve Sanat Yayınları 2013.

Kepecioğlu, Kamil: Bursa Kütüğ̈̈, IV, haz. Hüseyin Algül, Osman Çetin, Mefail Hız1, Mustafa Kara, M. Asım Yediyıldız, Bursa: Bursa Büyükşehir Belediyesi Yayınları 2009.

Keskin, Mustafa Çağhan: "Syrian-Origin Architects Around Amasya Region in the Early 15th Century", A|Z ITU Journal of the Faculty of Architecture, 12/2 (2015), s. 19-33.

Keskin, Mustafa Çağhan: "Bayezid Paşa: Vezir, Entelektüel, Sanat Hamisi”, Osmanlı Araşttrmaları, 48 (2016), s. 1-37.

Kılc1, Ali: "Erken Osmanlı (1299-1451) Baldaken Türbeleri”, Vakıflar Dergisi, XXIX (2005) s. 255-286. 
Kim, Sooyong: "Literary Culture in Fifteenth-Century Kütahya: A Preliminary Assessment", Islamic Literature and Intellectual Life in Fourteenth-and Fifteenth-Century Anatolia, ed. A. C. S. Peacock, Sara Nur Yıldız, Würzburg: Ergon, 2016, s. 383-400.

Konyalı, İbrahim Hakkı: Abideleri ve Kitabeleri ile Erzurum Tarihi, Erzurum: Ercan Matbaası 1960 .

Konyalı, İbrahim Hakkı: Abideleri ve Kitabeleri ile Karaman Tarihi Ermenek ve Mut Abideleri, İstanbul: Baha Matbaası 1967.

Koyunoğlu, Memduh Turgut: Iznik ve Bursa Tarihi, Bursa: Bursa Vilayet Matbaası 1935.

Kuban, Doğan: Osmanlı Mimarisi, İstanbul: YEM Yayınları 2007.

Kunter, Halim Baki: "Kitabelerimiz”, Vakıflar Dergisi, II (1942), s. 445-446.

Küçükcan, İlyas: Nacolea'dan Seyitgazi'ye Seyyid Battal Gazi ve Külliyesi, Eskişehir: Seyyid Battal Gazi Vakfi 2009.

Mantran, Robert: "Les Inscriptions Turques de Brousse”, Oriens, XII (1959), s. 118-121.

Mehmed Neşrî: Neşrî Tarihi, II, haz. Mehmet Altay Köymen, Ankara: Kültür ve Turizm Bakanlığı Yayınları 1984.

Moutafchieva, Vera: Agrarian Relations in the Ottoman Empire in the 15th and 16th Centuries, New York: Colombia University Press 1988.

Muallim Cevdet: “Bursa'da Gazi Umur Bey Camii Kitâbesi ve Bir Kaç Mühim Kitap”, Türk Tarih Arkeoloji ve Etnoğrafya Dergisi, II (1934), s. 258-261.

Necipoğlu, Gülru: The Age of Sinan: Architectural Culture in the Ottoman Empire, Princeton: Reaktion 2005.

Papagianni, Eleutheria: "Legal Institutions and Practice in Matters of Ecclesiastical Property", The Economic History of Byzantium From the Seventh through the Fifteenth Century, vol. 1, ed. Angeliki E. Laiou, Washington, D.C.: Dumberton Oaks Research Library and Collection, 2002, s. 1037-1047.

Özcan, Alir Rıza: İstanbul’un 100 Kitabesi, İstanbul: İstanbul Büyükşehir Belediyesi 2011.

Özel, Oktay: "Limits of the Almighty: Mehmed II's 'Land Reform' Revisited”, Journal of the Economic and Social History of the Orient, 42/2 (1999), s. 226-246.

Özkılıç, Sema Küçükalioğlu: 1894 Depremi ve İstanbul, İstanbul: Türkiye İş Bankası Yayınları 2015.

Solak-zâde, Mehmed Hemdemî Çelebî: Solak-zâde Tarihi, I, haz. Vahid Çabuk, Ankara: Kültür Bakanlığı Yayınları 1989.

Stanley, Tim: “The Books of Umur Bey”, Muqarnas, XXI (2004), s. 323-332.

Sucu, Cevat: Rûm'da Kozmopolit Model Kurmak: Däi ve 15. Yüzynl Osmanlı Metin Kültürü (Yayımlanmamış Yüksek Lisans Tezi), Ankara: İhsan Doğramacı Bilkent Üniversitesi Ekonomi ve Sosyal Bilimler Enstitüsü, 2017. 
Şikârî: Karamannâme: [Zamanın Kahraman Karamanîler'in Tarihi], haz. Metin Sözen, Necdet Sakaoğlu, İstanbul: Karaman Valiliği-Karaman Belediyesi Yayını 2005.

Şeker, Mehmet: "Vakfiyelerin Türk Kültürü Bakımından Özellikleri”, Ege Üniversitesi Edebiyat Fakültesi Tarih İncelemeleri Dergisi, VIII (1993), s. 1-18.

Şentürk, Ahmet Atillâ: Osmanlı Şiir Antolojisi, İstanbul: Yapı Kredi Yayınları 2009.

Tanındı, Zeren: "15th-Century Ottoman Manuscripts and Bindings in Bursa Libraries", Islamic Art, IV (1991), s. 143-174.

Tarım, Cevat Hakkı: Kırşehir Tarihi, Kırşehir: Kırşehir Vilayet Matbaası 1938.

Taşköprülüzâde, İsâmuddin Ebu'l-Hayr Ahmet Efendi: Osmanlı Bilginleri: eş-Şakâiku’nNumâniyye fî ulemâi'd-Devleti'l Osmâniyye, çev. Muharrem Tan, İstanbul: İz Yayıncrlik 2007.

Tursun Bey: Târih-i Ebü'l-feth, haz. Mertol Tulum, İstanbul: İstanbul Fetih Cemiyeti 1977.

Tüfekçioğlu, Abdülhamit: "Medeniyet Tarihimizde Taş Vakfiyeler”, Yüzüncü Yıl Üniversitesi Sosyal Bilimler Enstitüsü Dergisi, I (2000), s. 33-52.

Tüfekçioğlu, Abdülhamit: Erken Dönem Osmanlı Mimarisinde Yazı, Ankara: T. C. Kültür Bakanlığı 2001.

Türkiye’de Vakıf Abideler ve Eski Eserler, III, Ankara: Vakıflar Genel Müdürlüğü 1983.

Tütüncü, Mehmet: “Türkiye'de En Eski Türkçe Kitabe Eskişehir Seyitgazi İlçesinde Bulundu”, Düş̈̈nce ve Tarih Dergisi, 8 (2015), s. 16-23.

Uğurlu, Kamil: "Has Bey Dârülhuffâzı", TDV İslâm Ansiklopedisi (DİA), XVI (Ankara 1997), s. 272-273.

Uysal, Ali Osman: Germiyanoğulları Beyliğinin Mimarî Eserleri, Ankara: Atatürk Kültür Merkezi Başkanlığı 2006.

Uzluk, Feridun Nâfiz: “Germiyanoğlu Yakub II Bey’in Vakfiyesi”, Vakıflar Dergisi, VIII (1969), s. 71-111.

Uzunçarşılı, İsmail Hakkı: "Karamanoğulları Devri Vesikalarından İbrahim Beyin Karaman İmareti Vakfiyesi”, Belleten, I/1 (1937), s. 56-164.

Uzunçarşılı, İsmail Hakkı: Anadolu Beylikleri ve Akkoyunlu, Karakoyunlu Devletleri, Ankara: Türk Tarih Kurumu Yayınları 2003.

Ünal, Rahmi Hüseyin: Erzurum Yakutiye Medresesi, Ankara: Kültür Bakanlığı Yayınları 1993.

Walker, Bethany J.: "Popular responses to mamluk fiscal reforms in Syria”, Bulletin D'études Orientales, LVIII (2009), s. 51-68.

Wittek, Paul: "Ankara'da bir İlhanî Kitabesi” Türk Hukuk ve İktisat Tarihi Mecmuası, I (1931), s. 161-164.

Yardım, Ali: Amasya Kaya Kitâbesi, Ankara: T.C. Amasya Valiliği Kültür Yayınları 2004. 
Yediyıldız, Bahaeddin: XVIII. Yüzyılda Türkiye'de Vakıf Müessesesi: Bir Sosyal Tarih Incelemesi, Ankara: Türk Tarih Kurumu Yayınları 2003.

Yurttaş, Hüseyin, Zeynep Köşklü: "Erzurum İli Vakfiyelerinde Taş Özetler”, Türk Dünyası, Dil ve Edebiyat Dergisi /Turkish World, Journal of Language and Litrature, 44 (2017), s. 355-379.

Yüksel, İ. Aydın: Osmanlı Mimârî̀inde II. Bâyezid, Yavuz Selim Devri (888-926/14811520), V, İstanbul: İstanbul Fetih Cemiyeti 1983.

Yüksel, İ. Aydın: Osmanl Mimârîsinde Känûnî Sultan Süleyman Devri (926-974/15201566): İstanbul, VI, İstanbul: İstanbul Fetih Cemiyeti 2004.

Yüksel, Murat: "Kara Timurtaşoğlu Umur Bey'in Bursadda Vakfettiği Kitaplar ve Vakıf Kayıtları", Türk Dünyası Arasstrrmalar, XXXI (1984), s. 134-147. 
